University of Nebraska - Lincoln

DigitalCommons@University of Nebraska - Lincoln

Agronomy \& Horticulture -- Faculty Publications

Agronomy and Horticulture Department

2018

\title{
Managing grazing lands to improve soils and promote climate change adaptation and mitigation: A global synthesis
}

\author{
Marcia DeLonge \\ Union of Concerned Scientists, MDelonge@ucsusa.org \\ Andrea D. Basche \\ University of Nebraska-Lincoln, abasche2@unl.edu
}

Follow this and additional works at: https://digitalcommons.unl.edu/agronomyfacpub

Part of the Agricultural Science Commons, Agriculture Commons, Agronomy and Crop Sciences Commons, Botany Commons, Horticulture Commons, Other Plant Sciences Commons, and the Plant Biology Commons

DeLonge, Marcia and Basche, Andrea D., "Managing grazing lands to improve soils and promote climate change adaptation and mitigation: A global synthesis" (2018). Agronomy \& Horticulture -- Faculty Publications. 1125.

https://digitalcommons.unl.edu/agronomyfacpub/1125

This Article is brought to you for free and open access by the Agronomy and Horticulture Department at DigitalCommons@University of Nebraska - Lincoln. It has been accepted for inclusion in Agronomy \& Horticulture -Faculty Publications by an authorized administrator of DigitalCommons@University of Nebraska - Lincoln. 
Published in Renewable Agriculture and Food Systems 33 (2018), pp 267-278.

doi 10.1017/S1742170517000588

Copyright (C) 2017 Cambridge University Press. Used by permission.

Submitted 15 July 2017; accepted 20 October 2017; published 4 December 2017.

\title{
Managing grazing lands to improve soils and promote climate change adaptation and mitigation: A global synthesis
}

\author{
Marcia DeLonge and Andrea Basche \\ Union of Concerned Scientists, Food and Environment Program, \\ 1825K, Street NW Suite 80o, Washington, DC, 20006, USA \\ Corresponding author - Marcia DeLonge, email MDelonge@ucsusa.org
}

\begin{abstract}
The potential to improve soils to help farmers and ranchers adapt to and mitigate climate change has generated significant enthusiasm. Within this discussion, grasslands have surfaced as being particularly important, due to their geographic range, their capacity to store substantial quantities of carbon relative to cultivated croplands and their potential role in mitigating droughts and floods. However, leveraging grasslands for climate change mitigation and adaptation will require a better understanding of how farmers and ranchers who rely on them for their livelihoods can improve management and related outcomes. To investigate opportunities for such improvements, we conducted a meta-analysis of field experiments that investigated how soil water infiltration rates are affected by a range of management options: adding complexity to grazing patterns, reducing stocking rates or extended rest from grazing. Further, to explore the relationships between observed changes in soil water infiltration and soil carbon, we identified papers that reported data on both metrics. We found that in $81.9 \%$ of all cases, responses of infiltration rates to identified management treatments (response ratios) were above zero, with infiltration rates increasing by $59 \cdot 3 \pm 7 \cdot 3 \%$. Mean response ratios from unique management categories were not significantly different, although the effect of extended rest $(67.9 \pm 8.5 \%, n=140$ from 31 experiments) was slightly higher than from reducing stocking rates (42.0 $\pm 10.8 \% ; n=63$ from 17 experiments) or adding complexity (34.0 \pm $14.1 \%, n=17$ from 11 experiments). We did not find a significant effect of
\end{abstract}


several other variables, including treatment duration, mean annual precipitation or soil texture; however, analysis of aridity indices suggested that grazing management may have a slightly larger effect in more humid environments. Within our database, we found that $42 \%$ of complexity studies, $41 \%$ of stocking rate studies and $29 \%$ of extended rest studies also reported at least some measure of soil carbon. Within the subset of cases where both infiltration rates and carbon were reported, response ratios were largely positive for both variables (at least $64 \%$ of cases had positive mean response ratios in all management categories). Overall, our findings reveal that a variety of management strategies have the potential to improve soil water infiltration rates, with possible benefits for soil carbon as well. However, we identified a shortage of well-replicated and detailed experiments in all grazing management categories, and call for additional research of both soil water and soil carbon properties for these critical agroecosystems.

Keywords: Climate adaptation, grassland management, grazing management, meta-analysis, organic matter, soil carbon, soil hydrology, stocking rates, water infiltration

\section{Introduction}

The potential for improved soil health to help farmers and ranchers adapt to and mitigate climate change has generated substantial enthusiasm among various stakeholders. While much of this conversation has centered on croplands and related conservation agriculture practices (Poeplau and Don, 2015; VandenBygaart, 2016), grasslands and grazing lands have gained increasing attention (Paustian et al., 2016; Teague et al., 2016). The significance of these grass and grazing-based systems is in part due to their wide geographic range; in the USA, there are about 777 million acres of grazing land (Nickerson et al., 2011), and about $25 \%$ of the global land surface is managed as grazing land (Asner et al., 2004). Further, grazing systems are the foundation of millions of livelihoods in the USA and hundreds of millions globally, and these lands and livelihoods are very vulnerable to climate change (Thornton et al., 2009; Sayre et al., 2013; Briske et al., 2015). Therefore, these areas represent a significant opportunity to address land sector solutions for climate adaptation and mitigation.

Grasslands provide numerous ecosystem services, including the capacity to store substantial quantities of soil carbon, reduce runoff and erosion, protect water quality, store water, reduce drought and flood risk, provide wildlife habitat and recreational areas, and support biodiversity (Franzluebbers et al., 2012; Werling et al., 2014; Yahdjian et al., 2015). Together, these services contribute to both climate change mitigation and adaptation, in 
addition to many other co-benefits. Despite their value, grasslands are being degraded and converted around the world, frequently to crop production systems (Wright and Wimberly, 2013; Gibbs and Salmon, 2014; Lark et al., 2015; Gage et al., 2016). Notably, many of these ecosystems are highly prone to erosion under cropland management and may be better ecologically suited to production of animal products in well-managed grazing systems (Peters et al., 2016). Identifying the best management practices that can maximize ecosystem services while maintaining farm profitability may be one way to protect and improve the ecological function of grasslands.

While uncertainties remain, several approaches to improve grazing land management have been proposed. These include identifying optimal stocking rates and adopting more complex grazing management strategies, for example, through rotational grazing, adaptive management practices (e.g., adaptive multipaddock grazing) or silvopasture (Mysterud, 2006; Heckman, 2015; Teague et al., 2016; Teague and Barnes, 2017). Other strategies involve integrating grazing and pastures into more intensively managed diverse cropping systems (Russelle et al., 2007; Sulc and Franzluebbers, 2014). Extended rest from grazing has also been adopted in an effort to restore lands and ecosystem services (Bock et al., 1993; Castellano and Valone, 2007; Jeddi and Chaieb, 2010; Allington and Valone, 2011). These strategies can have different impacts and tradeoffs related to ecosystems, livelihoods and other socio-economic factors (Rivera-Ferre et al., 2016).

Among the many ecosystem services affected by grazing land management, climate change resilience is especially critical given increasing rainfall variability (Pryor et al., 2014). One approach to adapting to rainfall variability is to improve conditions for effective water management in soils, enabling them to capture more rainfall and make it available to plants during drier times (Stroosnijder et al., 2012; Stewart and Peterson, 2015). A variety of chemical, physical and biological soil processes affect soil water storage, but a key driver is infiltration rate, the rate of water entry into the soil (Hillel, 1998). Soil water content also has strong links to soil carbon and soil organic matter contents (Hudson, 1994; Emerson, 1995), variables that can be affected in response to both crop and grazing land management (Conant et al., 2001; Wright et al., 2004; Franzluebbers et al., 2012; McSherry and Ritchie, 2013; McDaniel et al., 2014; Poeplau and Don, 2015; Paustian et al., 2016). Other factors affecting soil water content include hydrological properties such as porosity and plant available water, which can also be improved in agricultural systems, such as by cover crops, perennial grasses and agroforestry (Basche and DeLonge, 2017).

Understanding soil water infiltration rates and how they change is useful given their role in enhancing soil water storage and because they are an indicator of soil health (Moebius-Clune et al., 2016). Importantly, infiltration rates differ between and among ecosystems; for example, infiltration rates 
are often higher on grasslands than croplands (Bharati et al., 2002; Ghosh et al., 2009), and can be even higher in agroforestry systems (Ketema and Yimer, 2014; Bayala and Wallace, 2015). Within grasslands, grazing management can influence infiltration rates; studies have found that rates tend to decrease as grazing pressure increases (Radke and Berry, 1993; Holechek et al., 2000; Bell et al., 2011; Kumar et al., 2012), and some comparisons of wellmanaged grazing systems have suggested that adding complexity to grazing patterns can improve or maintain infiltration rates relative to continuous grazing (Thurow, 1991; Teague et al., 2011). Areas where grazing has been excluded can also have higher infiltration rates. For example, a recent analysis of Australian grazing lands found significant declines in ecosystem structure and function, including hydrological processes such as water infiltration and soil water, when cattle or sheep were introduced to previously ungrazed fields; however, this analysis did not focus on opportunities to improve outcomes with grazing management (Eldridge et al., 2016).

While many individual studies exist, to our knowledge, there are no quantitative reviews of the effect of improved grazing land management practices on soil water, particularly for infiltration rates. Furthermore, we know of no reviews that evaluate how soil water properties and soil carbon sequestration may be jointly affected by management changes in grazing systems. The primary goal of this study is to investigate the potential of different management practices on grass-based grazing systems to improve water infiltration rates. A secondary goal was to evaluate the degree to which experiments on this topic have also explored relationships between soil water infiltration rates and soil carbon. This analysis builds on other recent work investigating impacts of cropland management practices (no-till, cover crops, crop rotations, perennials, cropland grazing) on infiltration rates, porosity and water retained at field capacity (Basche and DeLonge, 2017; Basche and DeLonge, In Preparation). In this analysis, we focus on management options for grass-based systems with a history of grazing.

\section{Methods}

\section{Literature search}

To investigate how soil water is affected by grazing management, we conducted a meta-analysis of grass-based field studies. We identified papers with the EBSCO Discovery Service ${ }^{\mathrm{TM}}$ using the keyword string 'infiltration AND graz*', and secondarily searched the USDA-NRCS Soil Health Literature database (USDA-NRCS, 2016), as detailed in Basche and DeLonge (2017). Ultimately, 37 papers (representing 221 paired comparisons) were included in the database. 


\section{Defining management practice categories}

Three management categories were used to group the studies in this analysis (Table 1), and these categories were defined as described below.

Increased grazing pattern complexity (12 experiments): Experiments were included in this category if they represented a switch from a continuous grazing system to a more complex or strategically managed system (Supplemental Material Table S1). This category primarily included cases where grazing was changed from continuous (year-round or seasonal) to complex (e.g., rotational, mob, adaptive, etc.) management. We also searched for cases of increasing management complexity through other variables, such as by moving from a fully grass-based system to silvopasture, but we only found one paper that met those criteria (Sharrow, 2007). This category generally included comparisons that added complexity while kept stocking rates (ha AU-1 yr-1) similar (see Supplemental Material Table S1).

Reduced stocking rates (17 experiments): Treatments were included in this category if they represented a reduction in grazing pressure without any clear changes to grazing land or grazing management complexity. Changes in stocking rates or densities were reported in database studies using a variety of variables (stocking rate, stocking density, residual phytomass, degradation, vegetation type; see Supplemental Material Table S2).

Extended rest from grazing (31 experiments): Numerous experiments from our search included treatments where livestock were excluded from grazing areas. In fact, $58 \%(10 / 17)$ of the grazing pattern complexity studies and $88 \%(15 / 17)$ of the stocking rate studies also included grazing exclosure measurements (Supplemental Material Tables S1 and S2). Additionally, 15 studies from our keyword search had measurements on exclosure only (Supplemental Material Table S3). While not the focus of our analysis, we included these studies to provide insight into the potential effects on land from extended rest from grazing. For these studies, we defined the experimental treatment as the exclosures (i.e., rested areas) and the controls to be the grazed treatments. We further categorized these studies based on what type of grazing the treatments were being rested from (complex versus continuous grazing patterns, and light, moderate, heavy or very heavy stocking rates). Treatment duration was defined as the time since rest from grazing began; this was not always equivalent to the time since introduction of the control grazing pattern, so in some cases the control treatment should be considered only a proxy for the grazed condition. This artifact of the available data also means that the responses to rest estimated here could be larger or smaller than what would likely be found in a well-controlled experiment. 
Table 1. Overview of experiments. All systems include either continuous (C) or rotational (R) grazing with stocking rates that are low $(\mathrm{L})$, moderate $(\mathrm{M})$, high $(\mathrm{H})$, very high $(\mathrm{VH})$ or uncertain $(\mathrm{n} / \mathrm{a}$, considered to be moderate for analysis). Studies are categorized overall as (a) grazing pattern complexity studies, where treatments are agroforestry (For), rotational grazing (R) or adaptive grazing (Ada); (b) stocking rate studies, where treatments are reduced grazing (represented as L, M or H); and (c) extended rest studies, with exclosure treatment(s) only. Studies in (a) or (b) that also have exclosure treatments are noted with an "E".

\begin{tabular}{|c|c|c|c|c|c|c|c|c|}
\hline & & Author (year) & Site & $\operatorname{Prec}(\mathrm{mm})$ & $\begin{array}{l}\text { Duration } \\
\text { (years) }\end{array}$ & System & $\begin{array}{l}\text { Stocking } \\
\text { rate }\end{array}$ & Treatment \\
\hline \multirow[t]{12}{*}{ (a) } & & Sharrow (2007) & USA, OR & 1085 & 11 & $\mathrm{C}$ & $\mathrm{n} / \mathrm{a}$ & For \\
\hline & \multirow[t]{2}{*}{$\mathrm{E}$} & Dedjir Gamougoun et al. (1984) & USA, NM & 384 & 12 & $\mathrm{C}$ & $\mathrm{H}$ & $\mathrm{R}$ \\
\hline & & Kumar et al. (2012) & USA, MO & 967 & 3 & $\mathrm{C}$ & M & $\mathrm{R}$ \\
\hline & $\mathrm{E}$ & McGinty et al. (1979) & USA, TX & 572 & 7 & $\mathrm{C}$ & $\mathrm{H}$ & $\mathrm{R}$ \\
\hline & \multirow[t]{2}{*}{$\mathrm{E}$} & Pluhar et al. (1987) & USA, TX & 680 & 24 & $\mathrm{C}$ & M & $\mathrm{R}$ \\
\hline & & Proffitt et al. (1995) & Australia & 307 & 1 & $\mathrm{C}$ & $\mathrm{n} / \mathrm{a}$ & Ada \\
\hline & \multirow[t]{2}{*}{$\mathrm{E}$} & Tadesse (2002a) & Ethiopia & 1360 & 4 & $\mathrm{C}$ & $\mathrm{H}$ & $\mathrm{R}$ \\
\hline & & Teague et al. (2010) & USA, TX & 648 & 3 & $\mathrm{C}$ & M & $\mathrm{R}$ \\
\hline & $E$ & Teague et al. (2011) & USA, TX & 820 & 9 & $\mathrm{C}$ & $\mathrm{H}$ & $\mathrm{R}$ \\
\hline & $E$ & Thurow et al. (1986) & USA, TX & 609 & 4 & $\mathrm{C}$ & $\mathrm{H}$ & $\mathrm{R}$ \\
\hline & $\mathrm{E}$ & Weltz and Wood (1986) & USA, NM & 426 & 2,3 & $\mathrm{C}$ & $\mathrm{H}, \mathrm{M}$ & $\mathrm{R}$ \\
\hline & $\mathrm{E}$ & Wood et al. (1981) & USA, TX & 680 & 4,20 & $\mathrm{C}$ & $M, M$ & $\mathrm{R}$ \\
\hline \multirow[t]{17}{*}{ (b) } & $\mathrm{E}$ & Bari et al. (1993) & Pakistan & 625 & 2 & C & $\mathrm{H}$ & $M, L$ \\
\hline & & Chartier et al. (2011) & Argentina & 258 & - & $\mathrm{C}$ & $\mathrm{H}$ & $M, L$ \\
\hline & $\mathrm{E}$ & Dedjir Gamougoun et al. (1984) & USA, NM & 384 & 3 & $\mathrm{C}$ & $\mathrm{H}$ & M \\
\hline & $\mathrm{E}$ & du Toit et al. (2009) & South Africa & 366 & 2 & C & $\mathrm{H}$ & $\mathrm{M}, \mathrm{L}$ \\
\hline & $\mathrm{E}$ & Franzluebbers et al. (2011) & USA, GA & 1250 & 12 & C & $\mathrm{H}$ & $L$ \\
\hline & $E$ & Mwendera and Saleem (1997) & Ethiopia & 1000 & 1 & $\mathrm{C}$ & $\mathrm{V}$ & $\mathrm{L}, \mathrm{M}, \mathrm{H}$ \\
\hline & $E$ & Pluhar et al. (1987) & USA, TX & 680 & 1 & $\mathrm{R}$ & V & $\mathrm{H}$ \\
\hline & $E$ & Savadogo et al. (2007) & Burkina Faso & 841 & 1 & $\mathrm{R}$ & $\mathrm{V}$ & $\mathrm{L}, \mathrm{M}, \mathrm{H}$ \\
\hline & $\mathrm{E}$ & Taddese et al. (2002b) & Ethiopia & 1000 & 1 & C & V & $\mathrm{L}, \mathrm{M}, \mathrm{H}$ \\
\hline & $\mathrm{E}$ & Tadesse et al. (2003) & Ethiopia & 1095 & 2 & C & $\mathrm{H}$ & M \\
\hline & $\mathrm{E}$ & Teague et al. (2011) & USA, TX & 820 & 9 & $\mathrm{C}$ & $\mathrm{H}$ & $\mathrm{L}$ \\
\hline & $E$ & Thurow et al. (1986) & USA, TX & 609 & 6 & C & $\mathrm{H}$ & M \\
\hline & \multirow[t]{2}{*}{$E$} & Warren et al. (1986a) & USA, TX & 609 & 1 & $\mathrm{R}$ & $\mathrm{V}$ & $\mathrm{M}, \mathrm{H}$ \\
\hline & & Warren et al. (1986b) & USA, TX & 609 & 2 & $\mathrm{R}$ & $\mathrm{H}$ & $M, L$ \\
\hline & $E$ & Weltz and Wood (1986) & USA, NM & 426 & 18 & C & $\mathrm{H}$ & $\mathrm{M}$ \\
\hline & $E$ & Wood et al. (1981) & USA, TX & 680 & 20 & C & $\mathrm{H}$ & M \\
\hline & $\mathrm{E}$ & Zhou et al. (2010) & China & 505 & 13 & $\mathrm{C}$ & $\mathrm{H}$ & M \\
\hline \multirow{14}{*}{\multicolumn{2}{|c|}{ (c) }} & Achouri and Gifford (1984) & USA, UT & 250 & 20 & $\mathrm{C}$ & M & \\
\hline & & Allington and Valone (2011) & USA, AZ & 395 & 40 & $\mathrm{R}$ & $\mathrm{n} / \mathrm{a}$ & \\
\hline & & Bharati et al. (2002) & USA, IA & 851 & 6 & $\mathrm{C}$ & - & \\
\hline & & Busby and Gifford (1981) & USA, UT & 345 & 5,1 & $\mathrm{R}$ & M & \\
\hline & & Castellano and Valone (2007) & USA, AZ & 350 & $52,25,10$ & C & - & \\
\hline & & Gifford (1982) & USA, ID & 305 & $1,2,4,6$ & C & - & \\
\hline & & Jeddi and Chaieb (2010) & Tunisia & 196 & 6,12 & C & - & \\
\hline & & Kato et al. (2009) & Mongolia & 181, & 213,1624 & C & $\mathrm{V}, \mathrm{H}, \mathrm{M}$ & \\
\hline & & Kauffman et al. (2004) & USA, OR & 320 & 7 & C & $\mathrm{n} / \mathrm{a}$ & \\
\hline & & Lavado and Alconada (1994) & Argentina & 950 & 3,12 & $\mathrm{C}$ & $\mathrm{H}$ & \\
\hline & & Takar et al. (1990) & Somalia & 446 & 3 & C & $\mathrm{H}$ & \\
\hline & & Tukel (1984) & Turkey & 362 & 30 & C & $\mathrm{H}$ & \\
\hline & & Tromble et al. (1974) & USA, AZ & 312 & 9 & - & - & \\
\hline & & Wheeler et al. (2002) & USA, CO & 407.7 & 39 & $C$ & $\mathrm{H}$ & \\
\hline
\end{tabular}




\section{Database development}

Data from studies were extracted and analyzed as systematically as possible, as described in Basche and DeLonge (2017). Our analysis only included values of steady-state infiltration (e.g., total volume of water infiltrated over a defined period). Further, multiple measurements reported in 1 yr were averaged, unless those measurements were distinctly different (due to experimental differences related to grazing management, slopes, soil textures, etc.). Additional variables were identified to assess the influence of different environmental or management factors. These included soil texture (percent sand, silt, clay), mean annual precipitation, treatment duration (number of years that a treatment was in place) and information on grazing (animal type, stocking rates and densities, annual days of grazing, days of rest between grazing, residual dry matter) (see Appendices 1-4). When available for both control and treatment conditions, we also extracted data on soil carbon or organic matter (concentrations or contents).

To supplement reported values, annual precipitation and temperature data were obtained from NOAA (Menne et al., 2012; https://www.ncdc.noaa. gov/cdo-web/datatools/normals ), and soil texture was retrieved from the US Department of Agriculture (Soil Survey Staff, 2017) for US locations only. When soil texture data were unavailable (seven of 37 studies), broader texture categories were defined if possible, based on soil textural descriptions (e.g., clay loam, loamy sand, etc.). Finally, we estimated aridity indices for all study sites using geographic coordinates, based on the CGIAR-CSI GlobalAridity Database (Zomer et al., 2006; Zomer et al., 2008).

\section{Statistical analysis}

The meta-analysis was conducted by calculating response ratios, representing a standardized comparison of the experimental to control treatments (Hedges et al., 1999).We calculated the natural log of the infiltration rate measured in the experimental treatment divided by the infiltration rate in the control treatment [Equation (1), e.g., more complex compared with more continuous management; reduced compared with greater stocking rates and extended rest from grazing compared with continued grazing]. Natural log results were back transformed to a percent change to ease interpretation, and results were considered significant if the $95 \%$ confidence intervals did not cross zero.

$$
\mathrm{LRR}=\ln \frac{\text { Experimental Infiltration Rate }}{\text { Control Infiltration Rate }}
$$


Many meta-analyses use weighting factors in statistical models to calculate mean treatment effects, which can include standard errors, standard deviations or experimental replications (Philibert et al., 2012). However, due to the limited reporting of standard errors or standard deviations, as well as the fact that many grazing studies did not include true replications (experimental designs frequently included only subsamples from larger areas or transects, as opposed to a true randomized block design), we performed an unweighted meta-analysis (Eldridge et al., 2016). Categories of grazing management (pattern complexity, stocking rates, extended rest) were analyzed separately, due to differences in experimental designs. A mixed model (lme4 package in R) was used to calculate category means and standard errors, including a random effect of study to account for similar study environments when experimental designs allowed for multiple paired observations (St-Pierre, 2001; Eldridge et al., 2016). For several of the continuous environmental variables (soil texture, mean annual precipitation and aridity index), regression coefficients were generated from a similar statistical model where environmental variables were considered fixed effects.

\section{Results}

\section{Infiltration database description}

We located 37 total experiments representing 221 paired observations from five continents that met the criteria for this analysis (Fig. 1a). The number of suitable experiments for this analysis was smaller, but comparable, to the number of experiments available for a companion study investigating impacts conservation agriculture techniques on infiltration rates in cropping systems (e.g., 52 experiments for no-till, 23 for cover cropping; Basche and DeLonge, In Preparation). The management practice that was most represented within the database was extended rest from grazing $(n=140$ paired comparisons), followed by reduced stocking rates $(n=63)$ and changes to pattern complexity $(n=18)$.

The studies within the database were diverse in several ways. For example, the types of grazing animals varied among experiments. For the complexity studies, six were cattle, two were sheep, three were mixed (including cattle, sheep and goats) and one was described as livestock only. For the stocking rate studies, nine were cattle, two were sheep, four were mixed and two were livestock, whereas studies investigating the effects of extended rest included nine focused on cattle, four on mixed systems and two on livestock. Additional variability occurred with respect to vegetation (ranging from annual to perennial grasses, shrubs and forested areas); grazing management 
(a)

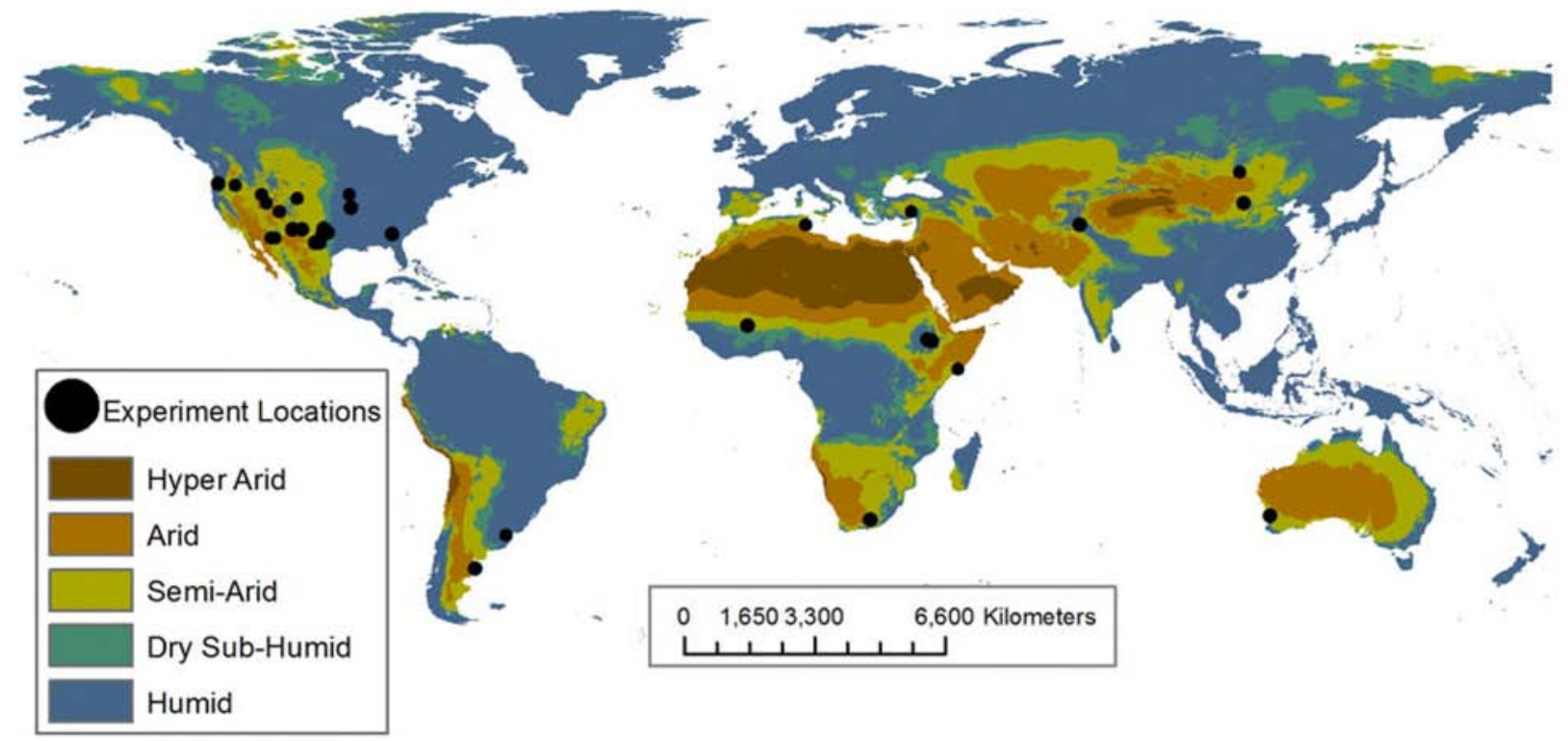

(b)

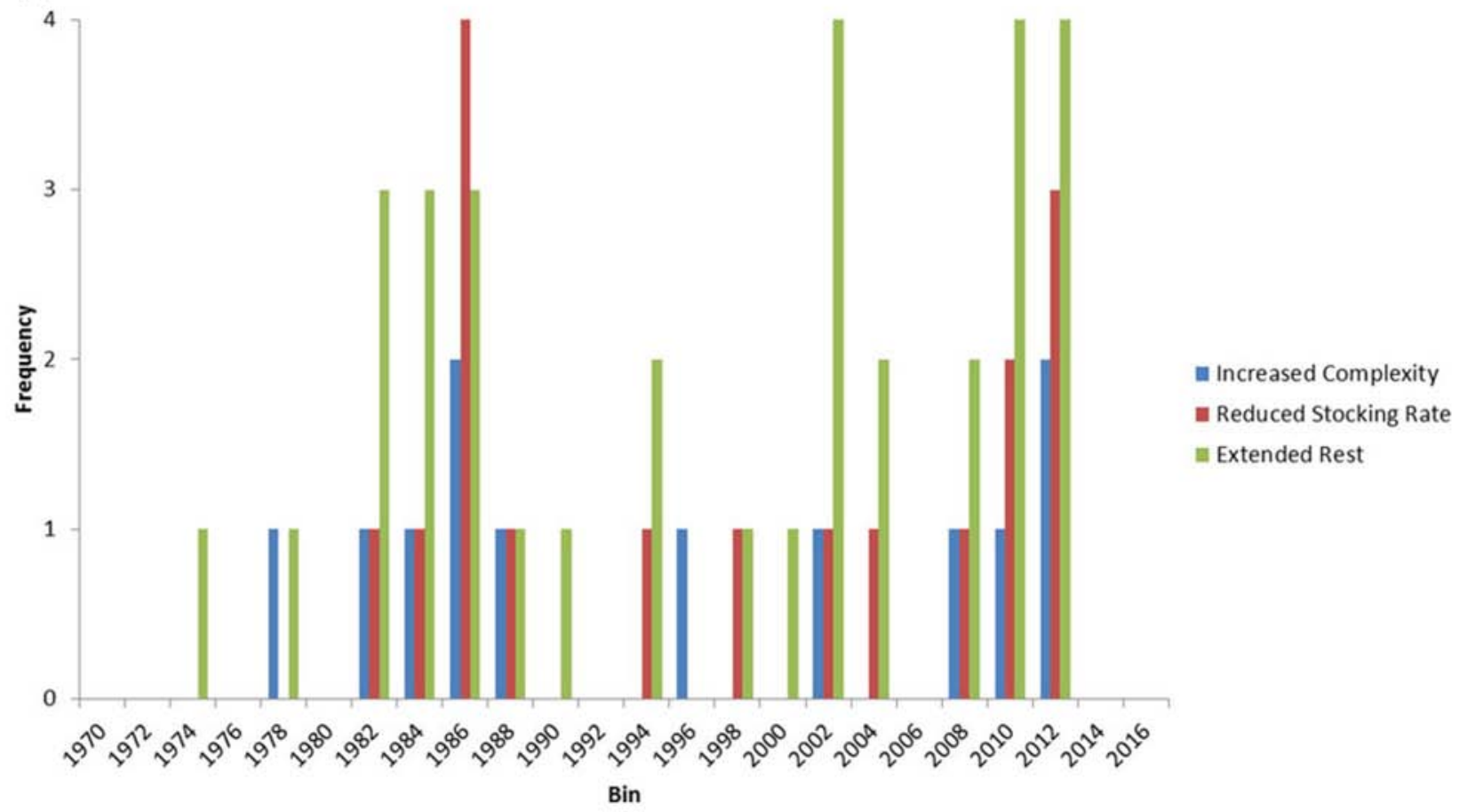

Fig. 1. (a) Geographic distribution of included studies (Africa: eight, Australia/New Zealand: one, Asia: four, South America: two, North America: 23 (22 in the USA)). Aridity indices are also shown for context. (b) Histogram showing timeline of publication of studies from each grazing management category. 
systems (including seasonal, rotational and adaptive grazing); and experimental design (ranging from replicated plots to cross-fence transects) (see Supplemental Material Tables S1-S3). Several studies were published over a decade ago (the first three were published between 1974 and 1980), but overall papers have been published at a steady rate (1-4 papers every $2 \mathrm{yr}$ ) for all management categories (Fig. 1b, Supplemental Material Tables S1S3). Histograms of response ratios for the database, separated by grazing management categories, did not reveal evidence of publication bias (Fig. 2).

\section{Response of infiltration rates to management changes}

Of the full dataset representing all practices, $81.9 \%$ of response ratios were above zero, indicating an increase in infiltration rates (Fig. 3a). Of the grazing management response ratios that included either changes to pattern complexity or stocking rate, $72.8 \%$ were above zero $(66.7$ and $74.6 \%$ from adding complexity and reducing stocking rates, respectively). An even larger percentage of studies investigating the impacts of extended rest had positive response ratios $(87.1 \%)$. Overall, results indicate that infiltration rates improved by $59.3 \pm 7 \cdot 3 \%$ following the implementation of the considered management practices (including adding complexity, reducing stocking rate and adopting extended rest from grazing; Fig. 3b). All individual management categories had mean response ratios significantly different from zero,

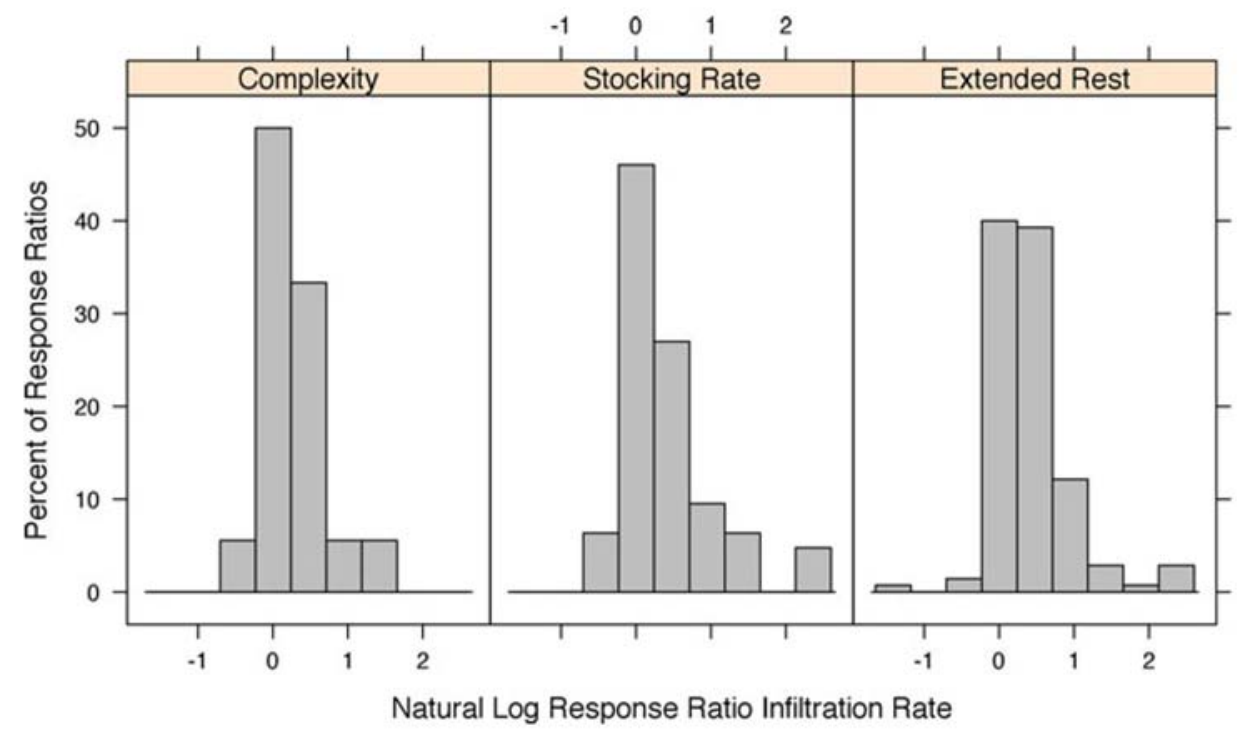

Fig. 2. Histograms of the natural log of response ratios to test for publication bias, separated by studies evaluating impacts of adding complexity to grazing patterns, reducing stocking rates or extended rest from grazing. 

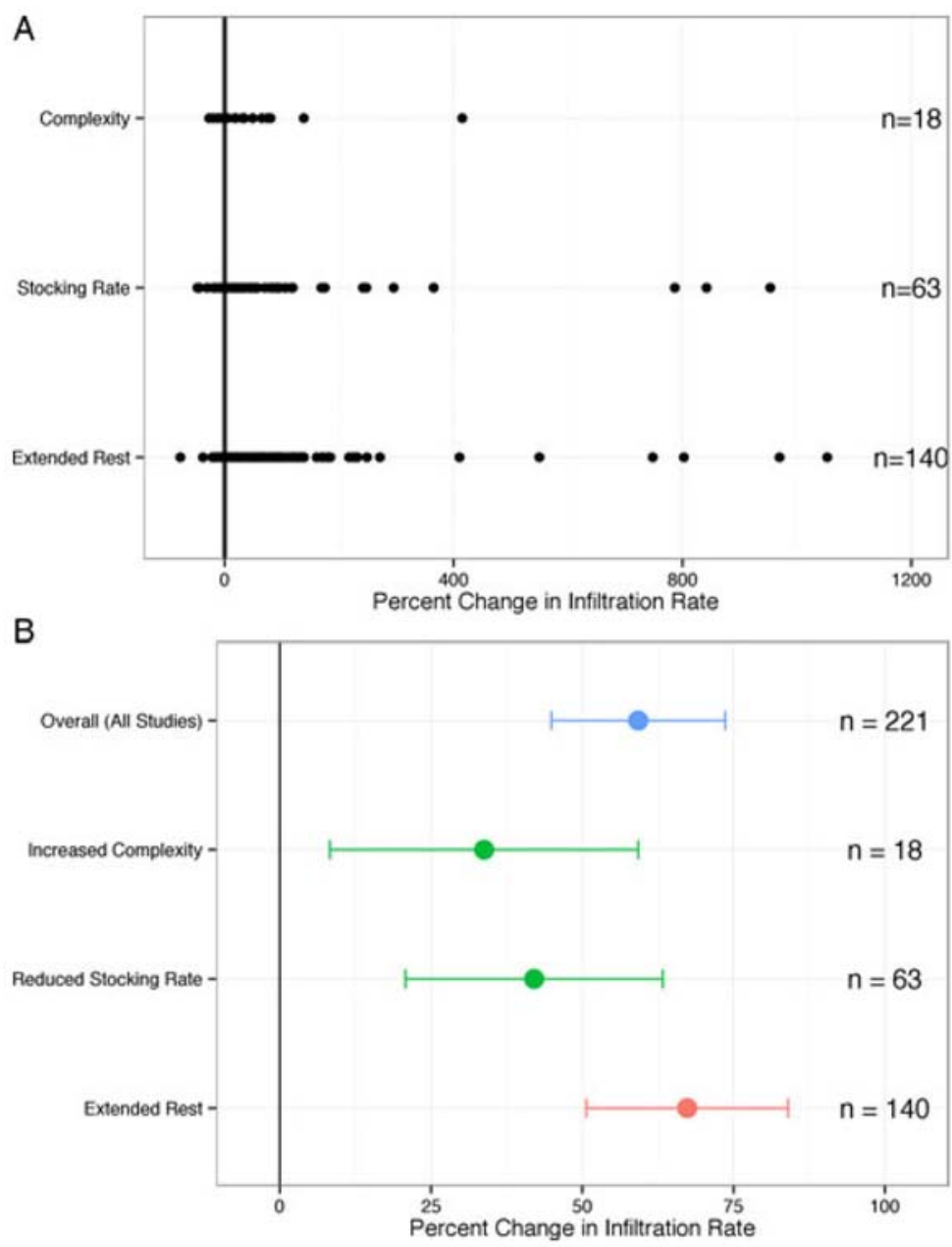

Fig. 3. (a) Influence of grazing system management on infiltration rates, separated by studies evaluating impacts of adding complexity to grazing patterns, reducing stocking rates or extended rest from grazing. (b) Mean response ratios $( \pm 95 \% \mathrm{CI})$ for the overall database and for various subsets of grazing system management (changes to pattern complexity, changes to stocking rate, extended rest). Results were considered statistically significant if error bars did not cross zero. Numbers of response ratios per subgroup are shown for reference.

including the categories with smaller sample sizes (changes to pattern complexity or stocking rate). There was no clear effect of treatment duration in any of the experiments, although several of the extended rest studies continued over relatively long periods; however, some studies suggested that relatively large differences could be possible within a short timeframe (Table 2, Supplemental Material Fig. S1).

We found no significant differences between or within the complexity, stocking rate and extended rest treatments, although the mean values and 
Table 2. Regression coefficients, $t$ - and $P$-values from statistical model considering key environmental variables as fixed effects

\begin{tabular}{|c|c|c|c|c|c|c|}
\hline & & $\begin{array}{l}\text { Mean annual. } \\
\text { precip }\end{array}$ & $\begin{array}{l}\text { Aridity } \\
\text { index }\end{array}$ & $\%$ Sand & \% Clay & $\begin{array}{l}\text { Treatment } \\
\text { duration }\end{array}$ \\
\hline \multirow[t]{4}{*}{ Overall database } & Reg.coef. & 0.000 & 0.242 & 0.006 & -0.010 & -0.001 \\
\hline & $t$-val & 0.497 & 0.717 & 1.649 & -2.244 & -0.270 \\
\hline & $P$-val & 0.624 & 0.478 & 0.108 & 0.034 & 0.788 \\
\hline & \# RRs & 221 & 221 & 185 & 185 & 219 \\
\hline \multirow[t]{4}{*}{ Complexity + stocking rate studies } & Reg.coef. & 0.001 & 0.278 & 0.006 & -0.016 & -0.007 \\
\hline & $t$-val & 2.129 & 0.677 & 1.113 & -2.586 & -0.408 \\
\hline & $P$-val & 0.084 & 0.505 & 0.277 & 0.015 & 0.685 \\
\hline & \# RRs & 8181 & 69 & 6979 & & \\
\hline \multirow[t]{4}{*}{ Extended rest studies } & Reg.coef. & 0.000 & 0.506 & 0.006 & -0.008 & -0.004 \\
\hline & $t$-val & 0.487 & 1.181 & 1.520 & -1.464 & -0.875 \\
\hline & $P$-val & 0.631 & 0.249 & 0.143 & 0.160 & 0.384 \\
\hline & \# RRs & 140 & 140 & 116 & 116 & 140 \\
\hline
\end{tabular}

$P$-values $\leq 0.1$ are shown in bold for convenience. Number of available response ratios (\# RRs) for each analysis shown for context.

confidence intervals differed. The mean response ratios for the added complexity and reduced stocking rate studies $(33.8 \pm 13.0 \%, n=18$ from $12 \mathrm{ex}-$ periments, and $42.0 \pm 10.8 \%, n=63$ from 17 experiments, respectively) were slightly lower than those from the extended rest studies (67.9 $\pm 8.5 \%$, $n=140$ from 31 experiments) (Fig. $3 \mathrm{~b}$ ). There was no significant difference between the effect of reducing stocking rate $(42.0 \pm 10.8 \% ; n=63$ from 17 experiments) and increasing complexity (33.8 $\pm 13.0 \%, n=18$ from 12 experiments). Likewise, we did not detect any significant differences when grazing was prevented from continuous versus more complex (rotational, adaptive, etc.) managed grazing systems (Fig. 4). Treatments that reported an exclosure from continuous grazing had slightly higher mean response ratios $(73.7 \pm 10.1 \%)$ and represented a greater number of the available studies $(n=119)$ as compared with the exclosures from more complex grazing patterns (50.4 $\pm 9.8 \%, n=23$ ) (Fig. 4).

We did not detect a clear relationship between the percent reduction in stocking rates and changes to infiltration rates (Supplemental Material Table S2 and Fig. S2). However, when we grouped the data in categories based on author descriptions of stocking rates, we found that the largest improvements in infiltration rates came from studies that reduced stocking rates from 'very heavy' to 'moderate' or 'low' stocking rates, as reported by authors (Fig. 5). There were relatively smaller differences in infiltration rates when the change in stocking rate was less pronounced, such as a change from 'very heavy' to 'heavy' or 'heavy' to 'moderate', and these groups exhibited changes that were not statistically different from zero. 


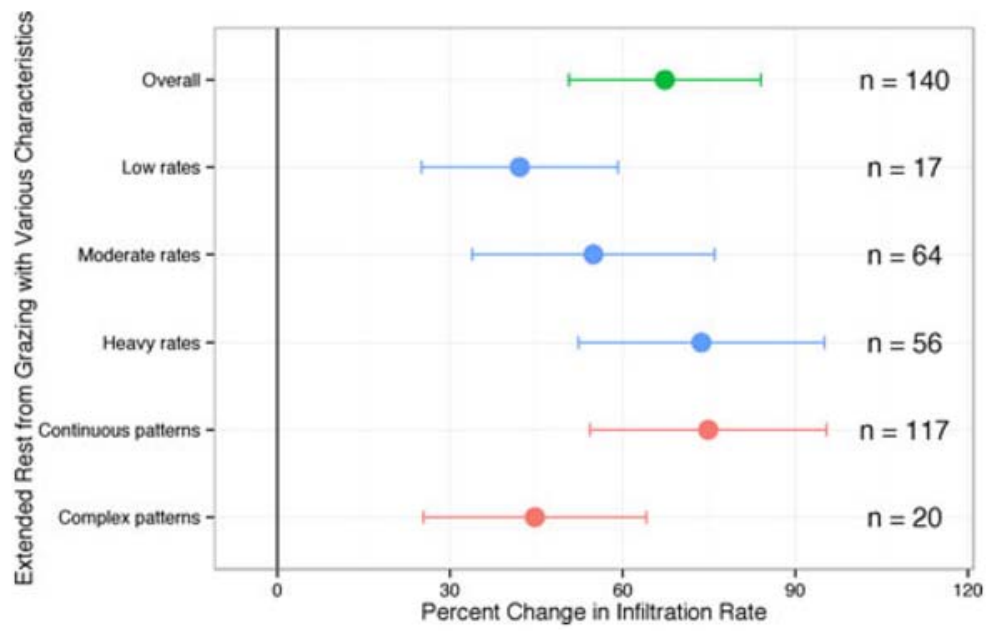

Fig. 4. Influence of extended rest on infiltration rates. Grouped mean response ratios ( $\pm 95 \% \mathrm{CI})$ are shown for all extended rest experiments (overall), as well as for subgroups of studies based on the control treatment grazing systems (systems with continuous or complex grazing patterns; systems with low, moderate or heavy stocking rates). Results were considered statistically significant if error bars did not cross zero.

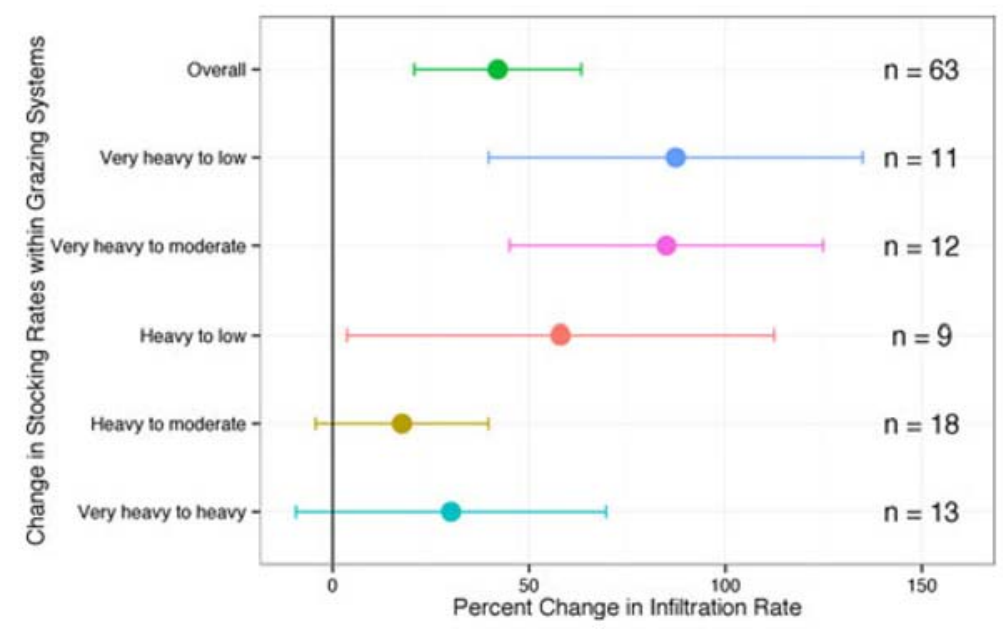

Fig. 5. Influence of changes to stocking rates on infiltration rates. Grouped means $( \pm 95 \% \mathrm{CI})$ are shown for all studies evaluating changes to stocking rates (overall) as well as within subgroups determined by the control shown (very heavy or heavy) and treatment (heavy, moderate or low) stocking rates. Means were considered statistically significant if error bars did not cross zero. 


\section{Influence of soil and climatic factors}

There were no clear patterns indicating relationships between management effects and climate variables (Table 2, Supplemental Material Figs S3 and S4). The strongest observed relationship was a pattern in the aridity indices, where regression coefficients indicated a greater effect of grazing management in environments that are more humid. Among the relatively few studies in humid environments (aridity index $>0.65 ; n=25$ from seven experiments), there were no negative response ratios and there was a larger mean effect compared with the experiments in more arid environments (Supplemental Material Fig. S3).

Similarly, we were unable to identify any strong relationships between management effects and soil texture, although there was some evidence that greater clay contents were more likely to lead to lower response ratios (Table 2, Supplemental Material Fig. S5). There was also a relatively wide range in sand content, and in experiments that altered stocking rates or grazing pattern complexity the soils with a higher sand content tended to have positive and relatively higher response ratios. For clay content, there was a slightly narrower range, and the only negative response ratios were observed in soils with higher clay contents ( $>30 \%$ ). However, it is important to note that only limited soil texture data were available in many of the studies.

Table 3. Availability of soil carbon or organic matter data (content or concentration, including measurements to any depth) in the database that was reported by grazing land management treatments within any of the studies

\begin{tabular}{lccccc} 
& & \multicolumn{3}{c}{ \# Paired comparisons } \\
\cline { 5 - 6 } $\begin{array}{l}\text { Grazing management } \\
\text { category }\end{array}$ & \# Studies & $\begin{array}{c}\text { \# Studies with } C \\
\text { measurements }\end{array}$ & $\begin{array}{c}\text { with C } \\
\text { data }\end{array}$ & $\begin{array}{c}\text { with C } \\
\text { increase }\end{array}$ & $\begin{array}{c}\text { C RR in same } \\
\text { direction as IR RR }\end{array}$ \\
\hline Pattern complexity & 12 & 5 & 6 & 4 & 4 \\
Stocking rate & 17 & 7 & 11 & 8 & 8 \\
Extended rest & 31 & 9 & 25 & 16 & 15 \\
\hline
\end{tabular}

The number of paired comparisons indicating an increase in the soil carbon metric is shown, as well as whether the treatment response ratio (RR) for the soil carbon metric tracked the observed response in infiltration rates (IR) (i.e., either both increased or both decreased). 


\section{Relationship between water infiltration and soil carbon impacts}

We found that very few studies rigorously investigated both soil water and soil carbon, but several of the infiltration studies in our database did include at least some measure of organic matter or carbon. Specifically, 42, 41 and $29 \%$ of the complexity, stocking rate and extended rest studies, respectively, reported at least some data related to soil carbon (a total of 42 paired observations, representing approximately $19 \%$ of the full database) (Table 3). Of the available paired comparisons, most cases were associated with increases in the soil carbon metric in response to treatments (64-73\% of paired comparisons, depending on management category). Similarly, in a majority of cases, the direction of the treatment effect (positive or negative) was the same in both the infiltration rate and soil carbon measurements (at least $60 \%$ of cases within all management categories). Finally, greater increases in soil carbon tended to be associated with higher increases in infiltration rates (Fig. 6).

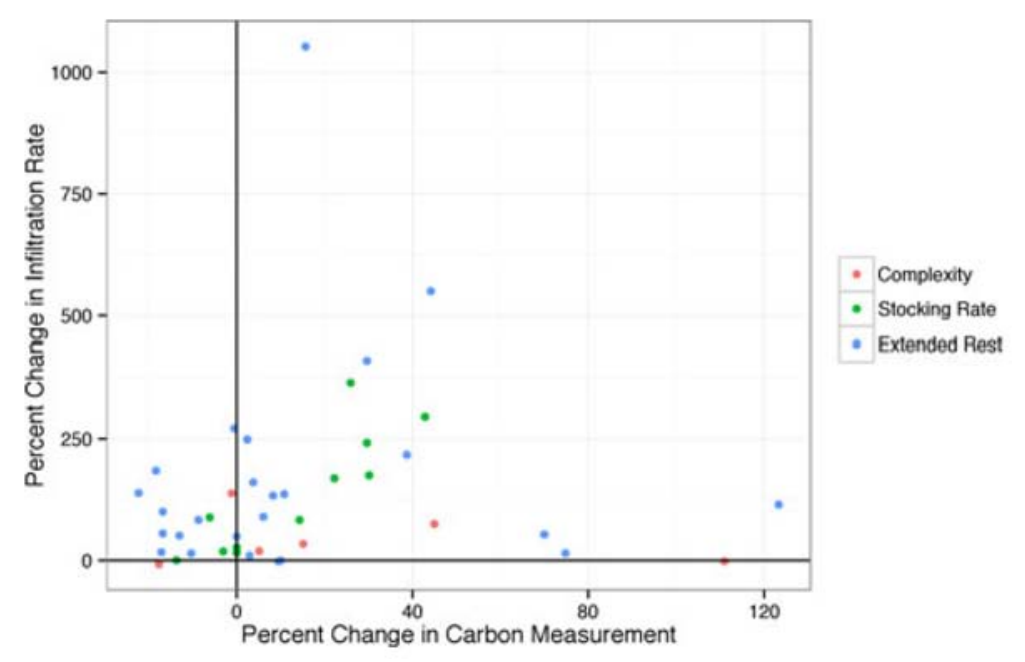

Fig. 6. Relationship between the percent changes in soil carbon or soil organic matter and infiltration rates for the subset of the database where sufficient data were reported for both properties (see Table 3). 


\section{Discussion}

Grazing management impacts on infiltration rates and soil carbon

Our analysis suggests that changes to grazing systems can increase infiltration rates, and that such improvements are possible through a variety of management strategies. These strategies include increasing grazing pattern complexity, in addition to reducing stocking rates or preventing grazing for an extended period. This finding is consistent with results from individual studies showing that infiltration rates can be increased by adding complexity to continuously grazed systems even at heavy stocking rates (Thurow, 1991), although such results have not been seen in all studies (e.g., Pluhar et al., 1987, Teague et al., 2010).

In addition, our results did not indicate any clear effect of treatment duration on the degree of improvements to infiltration rates. This finding is consistent with past studies that have found that high inter-annual variability in precipitation in combination with slow recovery processes could mean that over $20 \mathrm{yr}$ are needed to see significant treatment effects in grazing systems (Castellano and Valone, 2007). Only select studies have documented a faster recovery of infiltration rates in grazing systems. For example, Gifford (1982) found that infiltration rates improved significantly after excluding livestock for just 6 yr. While our study did identify select cases where relatively large improvements were achieved within short treatment durations, the lack of a significant trend and constraints in defining treatment duration (described earlier) suggested that substantial results are unlikely over short timeframes.

Our analysis of environmental factors suggests that infiltration rate improvements are possible in a wide range of climatic and soil conditions. Although there were no statistically significant differences when comparing response ratios by aridity or rainfall, there was some evidence to suggest slightly greater improvements in more humid environments. This trend was consistent with findings from another meta-analysis looking at conservation agriculture impacts on infiltration rates (Basche and DeLonge, In Preparation; for no-till and crop rotation practices). On the other hand, the trend conflicted with results from a meta-analysis of the effects of continuous living cover on porosity and water retained at field capacity, where treatment effects were strong in more arid environments (Basche and DeLonge, 2017). Finally, the lack of an effect of soil texture in our study could by explained in part by the limited availability of data. However, soil texture has also been shown to have only a weak effect on soil variables in other metaanalyses related to agricultural management (McDaniel et al., 2014; Poeplau and Don, 2015) 
Despite the importance of soil organic matter or carbon content for soil water properties (Hudson, 1994; Emerson, 1995), we found that few studies have rigorously investigated and reported results on both soil water infiltration and carbon. Nevertheless, our findings did indicate that the grazing treatments leading to improved infiltration rates were frequently associated with increases in soil organic matter or carbon content (although data were often very limited, in terms of replications, soil depth, etc.). This finding is similar to results from another study that showed that agricultural practices (e.g., cover crops, perennials) known to increase soil carbon can significantly improve infiltration rates (Basche and DeLonge, In Preparation). The concurrent effect of grazing management on both increased infiltration rates and soil carbon could result from enhanced biological activity that follows reduced soil disturbance. For example, it is understood that reduced soil disturbance increases earthworm activity and contributes to soil aggregation, which can increase water entry into the soil (Metting, 1993; Tomlin et al., 1995; Bronick and Lal, 2005; Briones and Schmidt, 2017). Rest from grazing for long periods of time (which occurred in both the extended rest and added complexity categories) could also facilitate greater plant growth, and as a result lead to increased root development and decomposition, which is known to improve soil structure and enhance water entry into the soil (Six et al., 2004).

\section{Grazing management impacts as compared with cropland management}

This study focused on grass-based grazing lands, but was part of a broader analysis that also investigated the management changes to conventional (annual) croplands. Interestingly, the improvements in soil water properties estimated in this study were on a similar order of magnitude as to what was observed in response to cropland management changes (Basche and DeLonge, 2017; Basche and DeLonge, In Preparation). Specifically, the mean improvements in this analysis were similar to the improvements in response to the introduction of perennials, and more reliably positive as compared to the implementation of crop rotations, no-till or cropland grazing. Of particular importance is the consideration that converting annual croplands to perennial systems (which are the foundation of the present study) offered the biggest overall benefit for cropland systems (Basche and DeLonge, In Preparation). With this broader perspective of agricultural lands, optimally managed grass-based grazing lands could offer even more significant water infiltration benefits relative to croplands. While we found very few studies that explicitly compared infiltration rates on croplands as compared with grassbased grazing lands (Bharati et al., 2002; Liebig et al., 2004; Ketema and Yimer, 2014), the available studies generally supported the idea that grazed grasslands had greater infiltration rates than nearby croplands. 


\section{Uncertainty and publication bias}

Meta-analyses are inherently limited by the available published literature that fits inclusion criteria. In this analysis, there were additional limitations in the experimental details reported by many of the included studies, and this could explain some of the uncertainty in trends. For example, many of the experiments did not include any information about soil texture (12/37 experiments included numeric values of soil texture), which required using the best available public data or the creation of broader texture categories for many locations in our database, which ultimately did not reveal definitive trends. Further, we tracked whether studies reported slope $(13 / 37)$ or aspect (4/37), but there were not enough experiments to perform a meaningful analysis with these variables. Some variables were reported relatively more frequently and in better detail, such as grazer type, plant communities and more specific details on stocking rates. However, given the already limited number of studies available for the full analysis, the subcategories within such variables were too limited to be analyzed for robust results.

Our study reveals the overall need for more well-replicated, randomized research experiments exploring the effects of changes to grazing management on soil water properties, especially infiltration rates, as well as on other metrics of soil health (such as soil carbon and organic matter). Our results also emphasize the importance of including clear and detailed data in publications, especially from field experiments investigating the effects of grazing on soil water properties, as these tend to be relatively complicated and rare. Recently, Gerstner et al. (2017) proposed a list of useful variables that field experiments should report to improve their likelihood of being valuable for follow-up studies, including meta-analyses and other syntheses. They suggested, for example, better description of environmental characteristics related to soil and climate. Similarly, Eagle et al. (2017) noted the importance of standardized and consistent agricultural field experiments (and related reporting) to ensure that data syntheses, such as meta-analyses, are most insightful. For grazing systems, they highly recommended inclusion of details on species, intensity and timing of grazing. We further propose that details on historical and current management practices are particularly needed; these may include typical periods of grazing and rest, treatment durations and any specific factors that managers may consider when adjusting such parameters.

Given the complexity of experimental designs and the lack of reported standard errors in the studies within our database, we were unable to perform a weighted meta-analysis. This likely did not have a large effect on the overall findings, however. A histogram of response ratios did not reveal evidence of publication bias (Fig. 2) and given the overall similar magnitude 
and direction of results observed across a range of grazing management approaches and environments, the soil processes likely to be responsible for infiltration rate increases appear to be robustly captured by our analysis.

\section{Conclusions}

Overall, our findings revealed that a variety of grazing management practices can improve soil water properties, including not only extended rest from grazing but also changes to grazing pattern complexity and stocking rates. Furthermore, a lack of significance of several experimental and environmental variables (e.g., treatment duration, mean annual precipitation, aridity index, soil texture) suggested that grazing management could improve soil infiltration rates across a wide range of conditions. However, our results were constrained due to the limited availability of studies within any management category that met the criteria for inclusion into the database.

In general, the findings from this study are significant given the expansiveness of grasslands and grazing lands, their role in livelihoods and ecosystem service provisioning, and their potential connection to both climate change adaptation and mitigation. However, we note that significant uncertainties result from the shortage of well-replicated experiments in all grazing management categories. Therefore, we call for additional research on opportunities to improve grassland management and ecosystem service outcomes, especially related to climate change adaptation and mitigation, for these critical agroecosystems.

Supplementary Material - The supplementary materials for this article follow the References.

Acknowledgments - The authors would like to thank the Union of Concerned Scientists Kendall Fellowship Program, as well as TomKat Foundation and The Grantham Foundation for the Protection of the Environment, for funding that supported the authors while writing this article. The authors would also like to thank Alexandra Parisien who was supported by the Duke University Stanback Internship Program while contributing to early stages of the design of this study, as well as Joy McNally and Jasmin Gonzalez for substantial assistance in database creation. Finally, the authors would like to thank Oliver Edelson, who contributed to the completion of the database and who was supported by Dartmouth College's Porter Family Fund for Sustainability in the Curriculum and the Richard and Jane Pearl Family Fund for Environmental Studies. 


\section{References}

Achouri M and Gifford GF (1984) Spatial and seasonal variability of field measured infiltration rates on a rangeland site in Utah. Journal of Range Management 37(5), 451-455.

Allington GR and Valone TJ (2011) Long-term livestock exclusion in an arid grassland alters vegetation and soil. Rangeland Ecology \& Management 64 (4), 424-428.

Asner GP, Elmore AJ, Olander LP, Martin RE and Thomas Harris A (2004) Grazing systems, ecosystem responses and global change. Annual Review of Environment and Resources 29(1), 261-299.

Bari F, Wood MK and Murray L (1993) Livestock grazing impacts on infiltration rates in a temperate range of Pakistan. Journal of Range Management 46(4), 367-372.

Basche AD and DeLonge M (2017) The impact of continuous living cover on soil hydrologic properties: a meta-analysis. Soil Science Society of America Journal 81(5), 1179-1190.

Basche AD and DeLonge M (In Preparation). Conservation and ecological practices improve water infiltration: a meta-analysis.

Bayala J, and Wallace JS (2015) The water balance of mixed tree-crop systems. In Ong CK, Black E and Wilson J (eds). Tree-Crop Interactions, 2nd edn., Agroforestry in a changing climate. Wallingford, UK: CAB International, pp. 146-190.

Bell LW, Kirkegaard JA, Swan A, Hunt JR, Huth NI and Fettell NA (2011) Impacts of soil damage by grazing livestock on crop productivity. Soil and Tillage Research 113, 19-29.

Bharati L, Lee K-H, Isenhart TM and Schultz RC (2002) Soil-water infiltration under crops, pasture, and established riparian buffer in Midwestern USA. Agroforestry Systems 56, 249-257.

Bock CE, Bock JH and Smith HM (1993) Proposal for a system of federal livestock exclosures on public rangelands in the Western United States. Conservation Biology 7(3), 731-733.

Briones MJ and Schmidt O (2017) Conventional tillage decreases the abundance and biomass of earthworms and alters their community structure in a global meta-analysis. Global Change Biology 23, 4396-4419.

Briske DD, Joyce LA, Polley HW, Brown JR, Wolter K, Morgan JA, McCarl BA and Bailey DW (2015) Climate-change adaptation on rangelands: linking regional exposure with diverse adaptive capacity. Frontiers in Ecology and the Environment 13, 249-256.

Bronick CJ and Lal R (2005) Soil structure and management: a review. Geoderma 24, 3-22.

Busby FE and Gifford GF (1981) Effects of livestock grazing on infiltration and erosion rates measured on chained and unchained pinyon-juniper sites in southeastern Utah. Journal of Range Management 34(5), 400-405. 
Castellano MJ and Valone TJ (2007) Livestock, soil compaction and water infiltration rate: evaluating a potential desertification recovery mechanism. Journal of Arid Environments 71, 97-108.

Chartier MP, Rostagno CM and Pazos GE (2011) Effects of soil degradation on infiltration rates in grazed semiarid rangelands of northeastern Patagonia, Argentina. Journal of Arid Environments 75, 656-661. Conant RT, Paustian K and Elliott ET (2001) Grassland management and conversion into grassland: effects on soil carbon. Ecological Applications 11(2), 343-355.

Dedjir Gamougoun ND, Smith RP, Wood MK and Pieper RD (1984) Soil, vegetation, and hydrologic responses to grazing management at Fort Stanton, New Mexico. Journal of Range Management 37(6), 538-541. du Toit G, van N, Snyman HA and Malan PJ (2009) Physical impact of grazing by sheep on soil parameters in the Nama Karoo subshrub/ grass rangeland of South Africa. Journal of Arid Environments 73, 804-810.

Eagle AJ, Christianson LE, Cook RL, Harmel RD, Miguez FE, Qian SS and Ruiz Diaz DA (2017) Meta-Analysis constrained by data: recommendations to improve relevance of nutrient management research. Agronomy Journal 109(6), 2441-2449.

Eldridge DJ, Poore AG, Ruiz-Colmenero M, Letnic M and Soliveres S (2016) Ecosystem structure, function and composition in rangelands are negatively affected by livestock grazing. Ecological Applications 26(4), 1273-1283.

Emerson W (1995) Water-retention, organic-C and soil texture. Soil Research 33, 241-251.

Franzluebbers AJ, Stuedemann JA and Franklin DH (2011) Water infiltration and surface-soil structural properties as influenced by animal traffic in the Southern Piedmont USA. Renewable Agriculture and Food Systems 27, 256-265.

Franzluebbers AJ, Paine LK, Winsten JR, Krome M, Sanderson MA, Ogles K and Thompson D (2012) Well-managed grazing systems: a forgotten hero of conservation. Journal of Soil and Water Conservation 67(4), 100A-104A.

Gage AM, Olimb SK and Nelson J (2016) Plowprint: tracking cumulative cropland expansion to target grassland conservation. Great Plains Research 26(2), 107-116.

Gerstner K, Moreno-Mateos D, Gurevitch J, Beckmann M, Kambach S, Jones HP and Seppelt R (2017)Will your paper be used in a meta-analysis? Make the reach of your research broader and longer lasting. Methods in Ecology and Evolution 8(6), 777-784, 10.1111/2041-210X.12758.

Ghosh PK, Saha R, Gupta JJ, Ramesh T, Das A, Lama TD, Munda GC, Bordoloi JS, Verma MR and Ngachan SV (2009) Long-term effect of pastures on soil quality in acid soil of North-East India. Australian Journal of Soil Research 47(4), 372-379.

Gibbs HK and Salmon JM (2015) Mapping the world's degraded lands. Applied Geography 57, 12-21.

Gifford GF (1982) A long-term infiltrometer study in southern Idaho, USA. Journal of Hydrology 58, 367-374. 
Heckman JR (2015) The role of trees and pastures in organic agriculture. Sustainable Agriculture Research 4(3), 51-59.

Hedges L, Gurevitch J and Curtis P (1999) The meta-analysis of response ratios in experimental ecology. Ecology 8o(4), 1150-1156.

Hillel D (1998) Environmental Soil Physics: Fundamentals, Applications, and Environmental Considerations. San Diego, CA: Academic Press.

Holechek JL, Gomes H, Molinar F, Galt D and Valdez R (2000) Short-duration grazing: the facts in 1999. Rangelands 22(1), 18-22.

Hudson BD (1994) Soil organic matter and available water capacity. Journal of Soil and Water Conservation 49(2), 189-194.

Jeddi K and Chaieb M (2010) Changes in soil properties and vegetation following livestock grazing exclusion in degraded arid environments of South Tunisia. Flora-Morphology, Distribution, Functional Ecology of Plants 205, 184-189.

Kato H, Onda Y, Tanaka Y and Asano M (2009) Field measurement of infiltration rate using an oscillating nozzle rainfall simulator in the cold, semiarid grassland of Mongolia. Catena 76, 173-181.

Kauffman JB, Thorpe AS and Brookshire EN (2004) Livestock exclusion and belowground ecosystem responses in riparian meadows of eastern Oregon. Ecological Applications 14, 1671-1679.

Ketema H and Yimer F (2014) Soil property variation under agroforestry based conservation tillage and maize based conventional tillage in Southern Ethiopia. Soil and Tillage Research 141, 25-31.

Kumar S, Anderson SH, Udawatta RP and Kallenbach RL (2012) Water infiltration influenced by agroforestry and grass buffers for a grazed pasture system. Agroforestry Systems 84, 325-335.

Lark TJ, Meghan Salmon J and Gibbs HK (2015) Cropland expansion outpaces agricultural and biofuel policies in the United States. Environmental Research Letters 10, 44003

Lavado RS and Alconada M (1994) Soil properties behavior on grazed and ungrazed plots of a grassland sodic soil. Soil Technology 7(1), 75-81.

Liebig M, Tanaka D and Wienhold B (2004) Tillage and cropping effects on soil quality indicators in the northern Great Plains. Soil and Tillage Research 78, 131-141.

McDaniel MD, Tiemann LK and Grandy AS (2014) Does agricultural crop diversity enhance soil microbial biomass and organic matter dynamics? A meta-analysis. Ecological Applications 24(3), 560-570.

McGinty WA, Smeins FE and Merrill LB (1979) Influence of soil, vegetation, and grazing management on infiltration rate and sediment production of Edwards Plateau rangeland. Journal of Range Management 32(1), 33-37.

McSherry ME and Ritchie ME (2013) Effects of grazing on grassland soil carbon: a global review. Global Change Biology 19, 1347-1357.

Menne MJ, Durre I, Vose RS, Gleason BE and Houston TG (2012) An overview of the global historical climatology network-daily database. Journal of Atmospheric and Oceanic Technology 29(7), 897-910. 
Metting FB Jr (ed.). (1993) Soil Microbial Ecology: Applications in Agricultural and Environmental Management. New York: Marcel Dekker.

Moebius-Clune BN, Moebius-Clune DJ, Gugino BK, Idowu OJ, Schindelbeck RR, Ristow AJ, van Es HM, Thies JE, Shayler HA,

McBride MB, Wolfe DW and Abawi GS (2016) Comprehensive Assessment of Soil Health - The Cornell Framework Manual, 3.1 edn., Geneva, NY: Cornell University.

Mwendera EJ and Saleem MM (1997) Hydrologic response to cattle grazing in the Ethiopian highlands. Agriculture, Ecosystems \& Environment 64(1), 33-41.

Mysterud A (2006) The concept of overgrazing and Its role in management of large herbivores. Wildlife Biology 12(2), 129-141.

Nickerson C, Ebel R, Borchers A and Carriazo F (2011) Major Uses of Land in the United States, 2007.Washington, DC: U.S. Department of Agriculture Economic Research Service.

Paustian K, Lehmann J, Ogle S, Reay D, Robertson GP and Smith P (2016) Climatesmart soils. Nature 532, 49-57.

Peters CJ, Picardy J, Darrouzet-Nardi AF, Wilkins JL, Griffin TS and Fick GW (2016) Carrying capacity of U.S. agricultural land: ten diet scenarios. Elementa: Science of the Anthropocene 4, 116.

Philibert A, Loyce C and Makowski D (2012) Assessment of the quality of metaanalysis in agronomy. Agriculture, Ecosystems and the Environment 148, 72-82.

Pluhar JJ, Knight RW and Heitschmidt RK (1987) Infiltration rates and sediment production as influenced by grazing systems in the Texas Rolling Plains. Journal of Range Management 40(3), 240-243.

Poeplau C and Don A (2015) Carbon sequestration in agricultural soils via cultivation of cover crops-a meta-analysis. Agriculture, Ecosystems \& Environment 200, 33-41.

Proffitt APB, Bendotti S and McGarry D (1995) A comparison between continuous and controlled grazing on a red duplex soil. I. Effects on soil physical characteristics. Soil and Tillage Research 35(4), 199-210.

Pryor SC, Scavia D, Downer C, Gaden M, Iverson L, Nordstrom R, Patz J and Robertson GP (2014) Ch. 18: Midwest. In Melillo JM, Richmond TC and Yohe GW (eds). Climate Change Impacts in the United States: The Third National Climate Assessment. U.S. Global Change Research Program. Washington, DC: U.S. Government Printing Office, pp. 418-440.

Radke JK and Berry EC (1993) Infiltration as a tool for detecting soil changes due to cropping, tillage, and grazing livestock. American Journal of Alternative Agriculture 8(4), 164-174.

Rivera-Ferre MG, López-i-Gelats F, Howden M, Smith P, Morton JF and Herrero M (2016) Re-framing the climate change debate in the livestock sector: mitigation and adaptation options: mitigation and adaptation options in the livestock sector. Wiley Interdisciplinary Reviews: Climate Change 7, 869-892.

Russelle MP, Entz MH and Franzluebbers AJ (2007) Reconsidering integrated crop-livestock systems in North America. Agronomy Journal 99(2), 325-334. 
Savadogo P, Sawadogo L, and Tiveau D (2007) Effects of grazing intensity and prescribed fire on soil physical and hydrological properties and pasture yield in the savanna woodlands of Burkina Faso. Agriculture, Ecosystems \& Environment 118, 80-92.

Sayre NF, McAllister RR, Bestelmeyer BT, Moritz M and Turner MD (2013) Earth stewardship of rangelands: coping with ecological, economic, and political marginality. Frontiers in Ecology and the Environment 11, 348-354.

Sharrow SH (2007) Soil compaction by grazing livestock in silvopastures as evidenced by changes in soil physical properties. Agroforestry Systems 71, 215-223.

Six J, Bossuyt H, Degryze S and Denef K (2004) A history of research on the link between (micro) aggregates, soil biota, and soil organic matter dynamics. Soil and Tillage Research 79, 7-31.

Soil Survey Staff (2017) Web Soil Survey. Washington, DC: USDA Natural Resources Conservation Service. Online http://websoilsurvey.nrcs.usda.gov/

St-Pierre NR (2001) Invited review: integrating quantitative findings from multiple studies using mixed model methodology. Journal of Dairy Science 84(4), 741-755.

Stewart B and Peterson G (2015) Managing green water in dryland agriculture. Agronomy Journal 107, 1544-1553.

Stroosnijder L, Moore D, Alharbi A, Argaman E, Biazin B and van den Elsen E (2012) Improving water use efficiency in drylands. Current Opinion in Environmental Sustainability 4(5), 497-506.

Sulc RM and Franzluebbers AJ (2014) Exploring integrated crop-livestock systems in different ecoregions of the United States. European Journal of Agronomy 57, 21-30.

Taddese G, Mohamed Saleem MA, Abyie A and Wagnew A (2002a) Impact of grazing on plant species richness, plant biomass, plant attribute, and soil physical and hydrological properties of vertisol in East African highlands. Environmental Management 29, 279-289.

Taddese G, Saleem MAM, Astatke A and Ayaleneh W (2002b) Effect of grazing on plant attributes and hydrological properties in the sloping lands of the East African highlands. Environmental Management 30, 406-417.

Taddesse G, Peden D, Abiye A and Wagnew A (2003) Effect of manure on grazing lands in Ethiopia, East African highlands. Mountain Research and Development 23, 156-16o.

Takar AA, Dobrowolski JP and Thurow TL (1990) Influence of grazing, vegetation life-form, and soil type on infiltration rates and interrill erosion on a Somalian rangeland. Journal of Range Management 43(6), 486-49o.

Teague R and Barnes M (2017) Grazing management that regenerates ecosystem function and grazing land livelihoods. African Journal of Range \& Forage Science 34(2), 77-86.

Teague WR, Dowhower SL, Baker SA, Ansley RJ, Kreuter UP, Conover DM and Waggoner JA (2010) Soil and herbaceous plant responses to summer patch 
burns under continuous and rotational grazing. Agriculture, Ecosystems \& Environment 137, 113-123.

Teague WR, Dowhower SL, Baker SA, Haile N, DeLaune PB and Conover DM (2011) Grazing management impacts on vegetation, soil biota and soil chemical, physical and hydrological properties in tall grass prairie. Agriculture, Ecosystems \& Environment 141, 310-322.

Teague WR, Apfelbaum S, Lal R, Kreuter UP, Rowntree J, Davies CA, Conser R, Rasmussen M, Hatfield J, Wang T, Wang F and Byck P (2016) The role of ruminants in reducing agriculture's carbon footprint in North America. Journal of Soil and Water Conservation 71(2), 156-164.

Thornton PK, van de Steeg J, Notenbaert A and Herrero M (2009) The impacts of climate change on livestock and livestock systems in developing countries: a review of what we know and what we need to know. Agricultural Systems 101, $113-127$.

Thurow TL (1991) Hydrology and Erosion. Grazing Management: An Ecological Perspective. Portland, Oregon: Timber Press, pp. 141-16o.

Thurow TL, Blackburn WH and Taylor CA Jr (1986) Hydrologic characteristics of vegetation types as affected by livestock grazing systems, Edwards Plateau, Texas. Journal of Range Management 39(6), 505-509.

Tomlin AD, Shipitalo MJ, Edwards WM and Protz R (1995) Earthworms and their influence on soil structure and infiltration. Earthworm Ecology and Biogeography in North America. Boca Raton, FL: CRC Press, pp. 159-184.

Tromble JM, Renard KG and Thatcher AP (1974) Infiltration for three rangeland soil vegetation complexes. Journal of Range Management 27(4), 318-321.

Tukel T (1984) Comparison of grazed and protected mountain steppe rangeland in Ulukisla, Turkey. Journal of Range Management 37(2), 133-135.

USDA-NRCS (2016) Soil Health Literature Database. Online http://www.nrcs. usda.gov/wps/portal/nrcs/detailfull/soils/health/?cid=stelprdb1257753 (Accessed 20 September 2016).

VandenBygaart AJ (2016) The myth that no-till can mitigate global climate change. Agriculture, Ecosystems \& Environment 216, 98-99.

Warren SD, Thurow TL, Blackburn WH and Garza NE (1986a) The influence of livestock trampling under intensive rotation grazing on soil hydrologic characteristics. Journal of Range Management 39(6), 491-495.

Warren SD, Blackburn WH and Taylor CA Jr (1986b) Soil hydrologic response to number of pastures and stocking density under intensive rotation grazing. Journal of Range Management 39(6), 500-504.

Weltz M and Wood MK (1986) Short duration grazing in central New Mexico: effects on infiltration rates. Journal of Range Management 39(4), 365-368.

Werling BP, Dickson TL, Isaacs R, Gaines H, Gratton C, Gross KL, Liere H, Malmstrom CM, Meehan TD, Ruan L, Robertson BA, Robertson GP, Schmidt TM, Schrotenboer AC, Teal TK, Wilson JK and Landis DA (2014) Perennial grasslands enhance biodiversity and multiple ecosystem services in bioenergy landscapes. Proceedings of the National Academy of Sciences 111, 1652-1657. 
Wheeler MA, Trlica MJ, Frasier GW and Reeder JD (2002) Seasonal grazing affects soil physical properties of a montane riparian community. Journal of Range Management 55(1), 49-56.

Wood MK and Blackburn WH (1981) Grazing systems: their influence on infiltration rates in the rolling plains of Texas. Journal of Range Management 34(4), 331-335.

Wright AL, Hons FM and Rouquette FM Jr (2004) Long-term management impacts on soil carbon and nitrogen dynamics of grazed Bermuda grass pastures. Soil Biology and Biochemistry 36, 1809-1816.

Wright CK and Wimberly MC (2013) Recent land use change in the Western Corn Belt threatens grasslands and wetlands. Proceedings of the National Academy of Sciences 110, 4134-4139.

Yahdjian L, Sala OE and Havstad KM (2015) Rangeland ecosystem services: shifting focus from supply to reconciling supply and demand. Frontiers in Ecology and the Environment 13(1), 44-51.

Zhou ZC, Gan ZT, Shangguan ZP and Dong ZB (2010) Effects of grazing on soil physical properties and soil erodibility in semiarid grassland of the Northern Loess Plateau (China). Catena 82, 87-91.

Zomer RJ, Trabucco A, van Straaten O and Bossio DA (2006) Carbon, Land and Water: A Global Analysis of the Hydrologic Dimensions of Climate Change Mitigation Through Afforestation/Reforestation. Colombo, Sri Lanka: International Water Management Institute. 44p. (IWMI Research Report 101).

Zomer RJ, Trabucco A, Bossio DA and Verchot LV (2008) Climate change mitigation: a spatial analysis of global land suitability for clean development mechanism afforestation and reforestation. Agriculture, Ecosystems \& Environment 126(1), 67-80. 
Supplemental Material Figure 1. Effect of duration of extended rest from grazing on infiltration rate response ratios. Data points representing extended rest from grazing systems with different levels of grazing intensities (low, moderate, heavy stocking rates) in either continuous or complex grazing patterns) are indicated. Only studies with treatment durations of 30 years or less are shown here (see Supplemental Material Table 3 ).

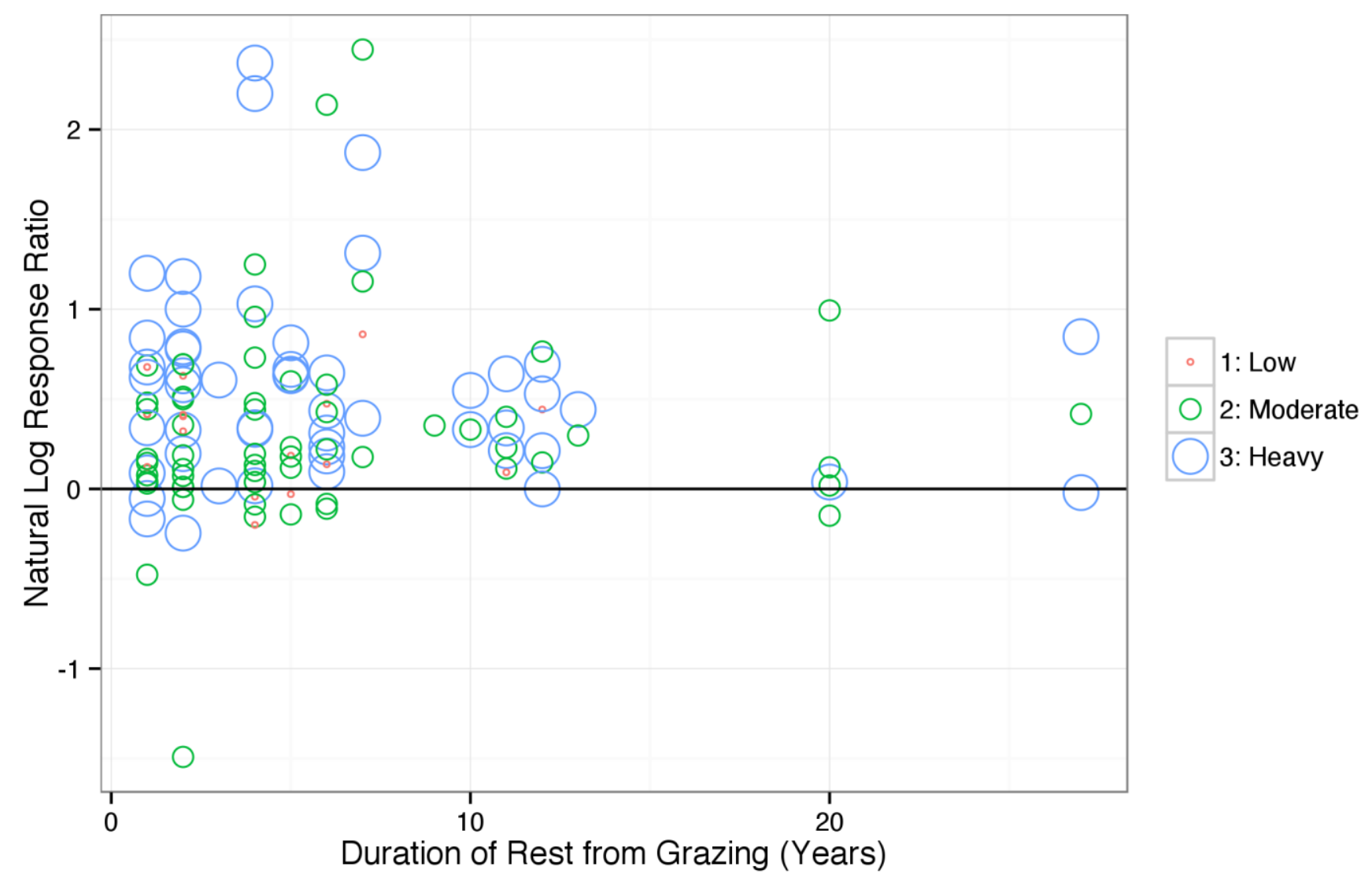


Supplemental Material Figure 2. Influence of the degree of stocking rate reduction (see Supplemental Material Table 2) on infiltration rate response ratios, for grazing rate studies only.

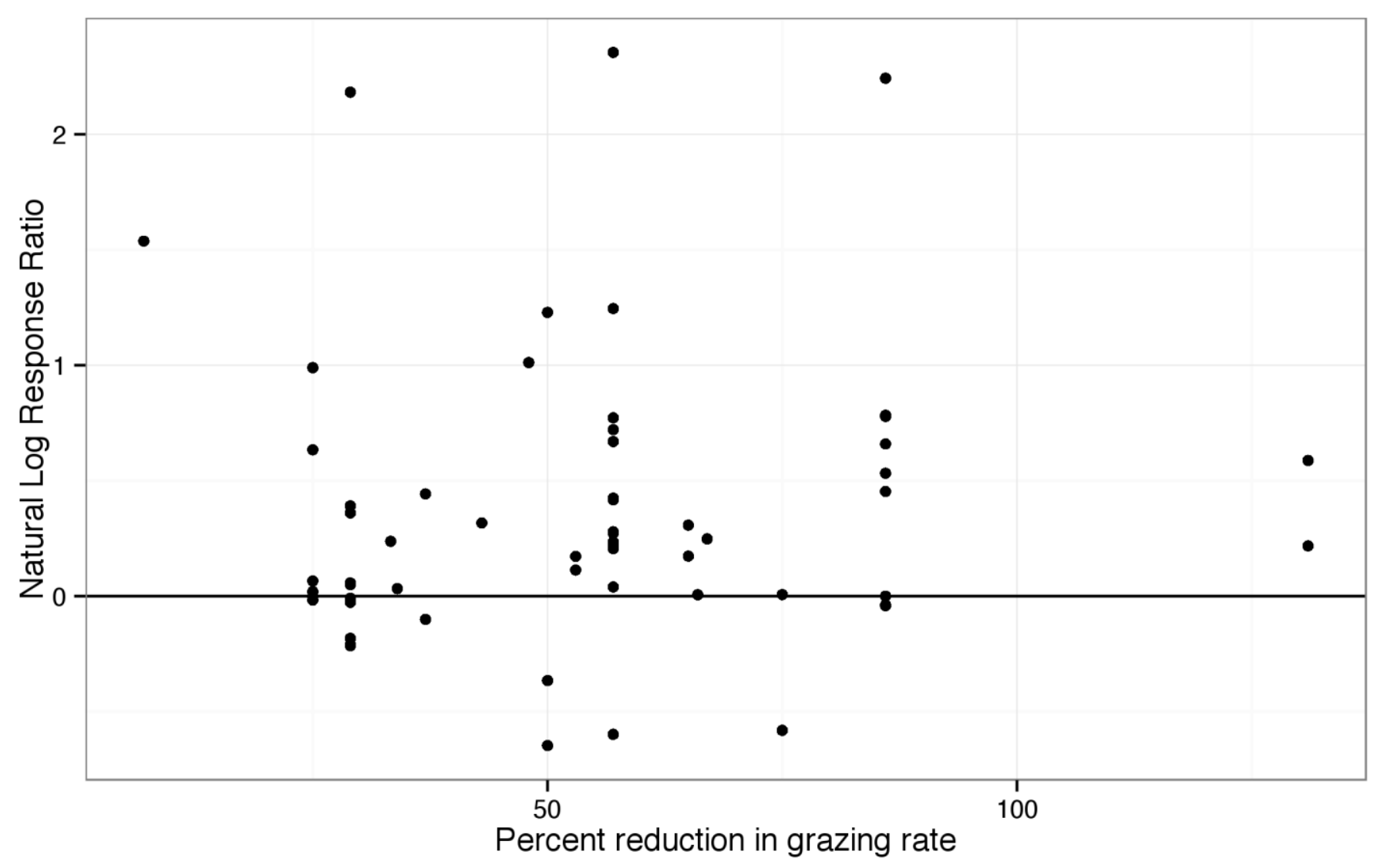


Supplemental Material Figure 3. Effect of aridity index on infiltration rate response ratios for (a) changes to grazing practices including adoption of agroforestry, increased grazing pattern complexity, and reduced stocking rates and (b) extended rest from grazing (from continuous and complex grazing patterns).
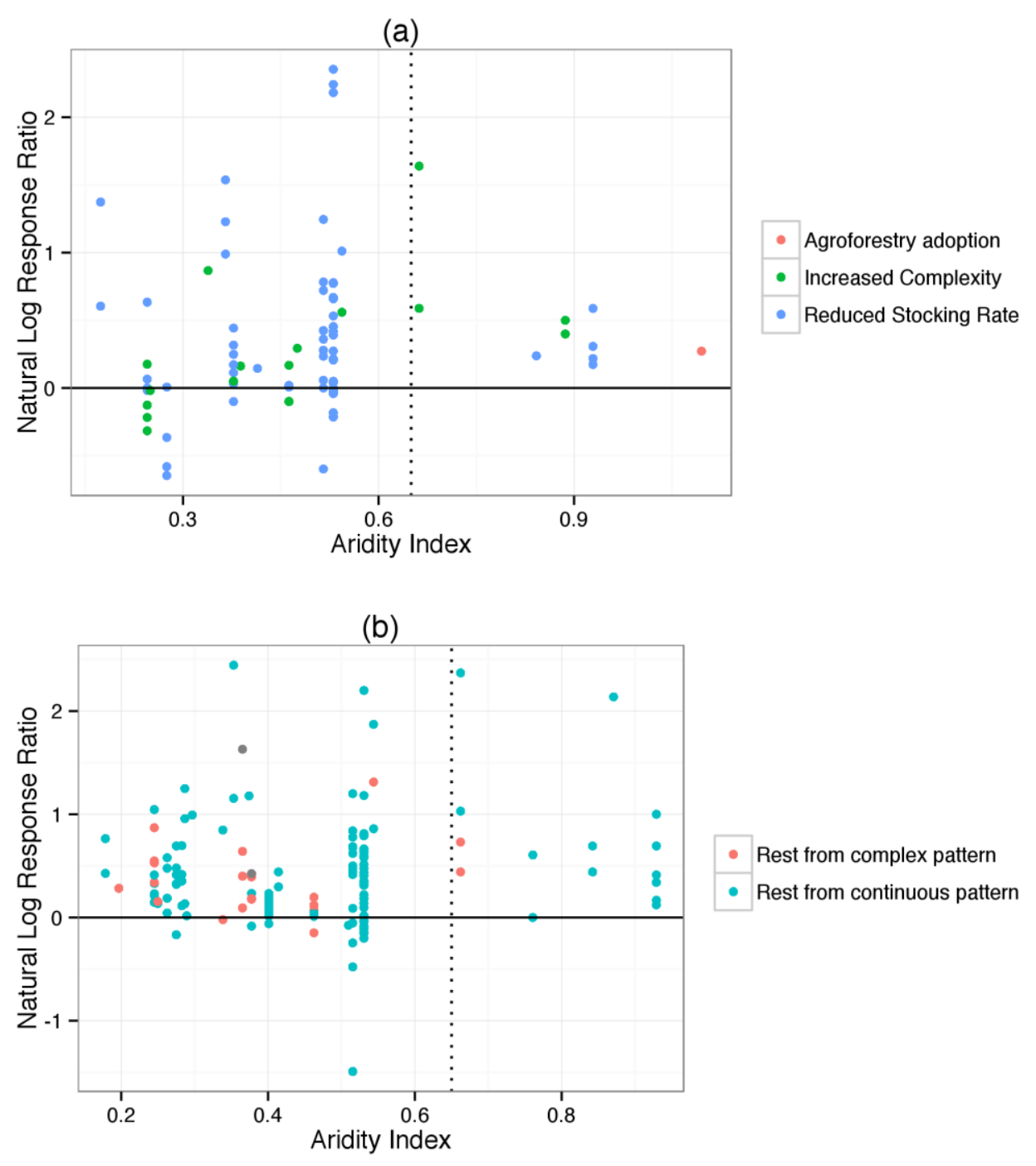
Supplemental Material Figure 4. Effect of mean annual precipitation on infiltration rate response ratios for (a) changes to grazing practices including adoption of agroforestry, increased grazing pattern complexity, and reduced stocking rates and (b) extended rest from grazing (from continuous and complex grazing patterns).
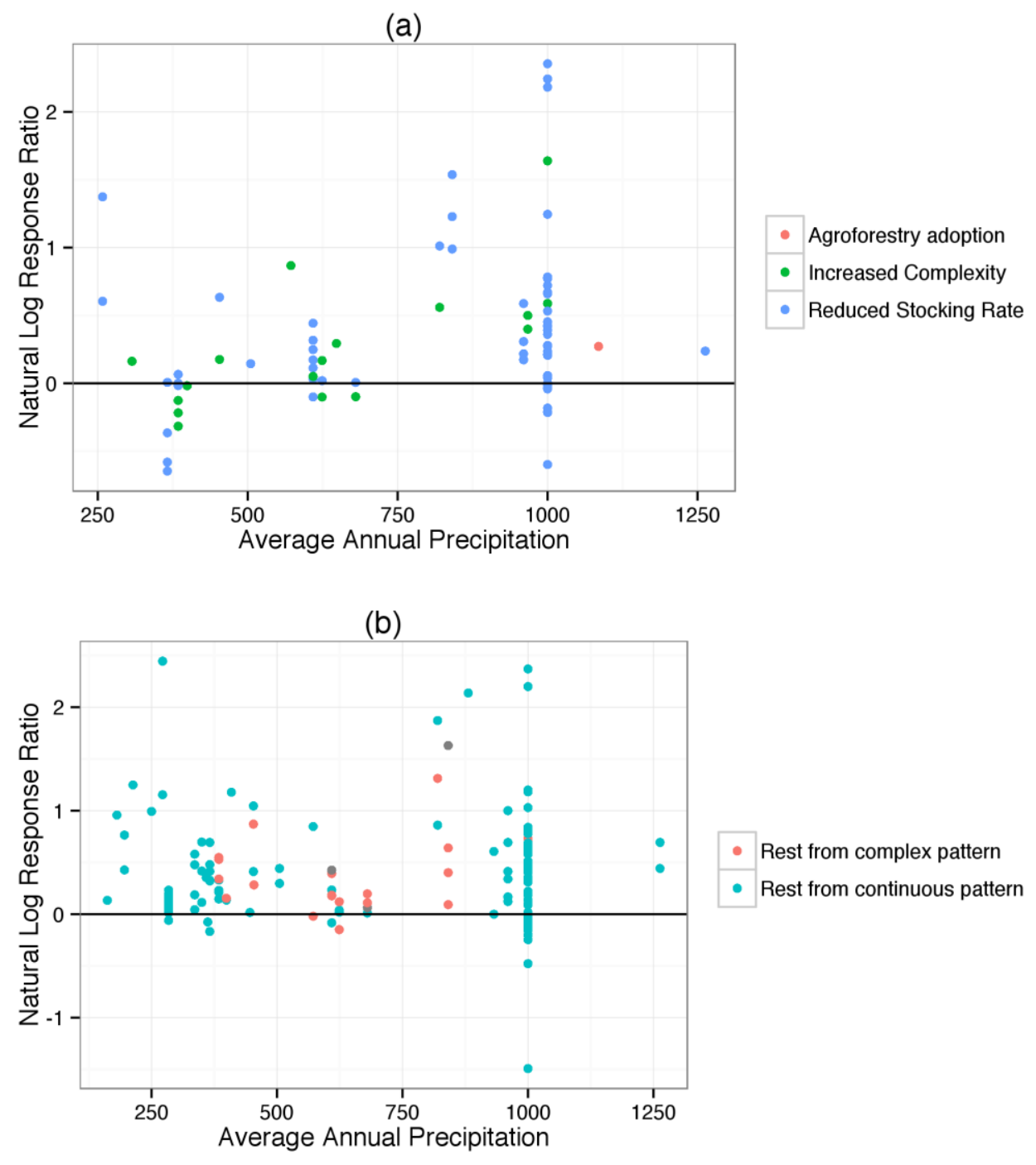
Supplemental Material Figure 5. Effect of soil texture on infiltration rate response ratios for (a, b) changes to grazing practices including adoption of agroforestry, increased grazing pattern complexity, and reduced stocking rates (5a: \% sand, 5b: \% clay) and (c, d) extended rest from grazing (from continuous and complex grazing patterns) (5c: \% sand, $5 \mathrm{~d}: \%$ clay).

(a)

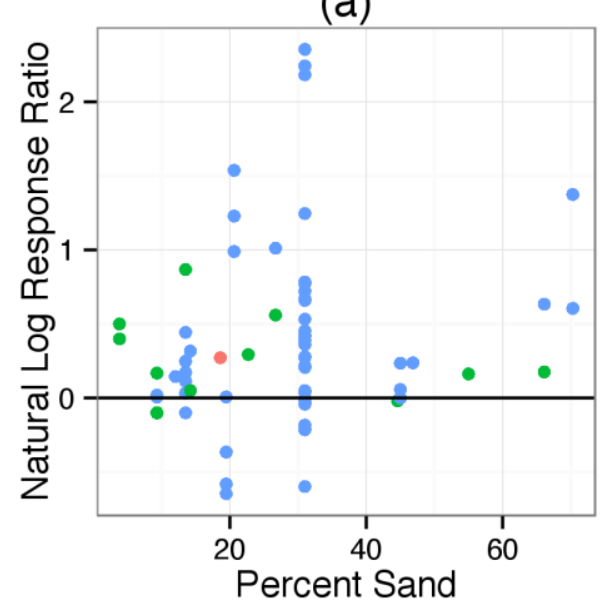

(c)

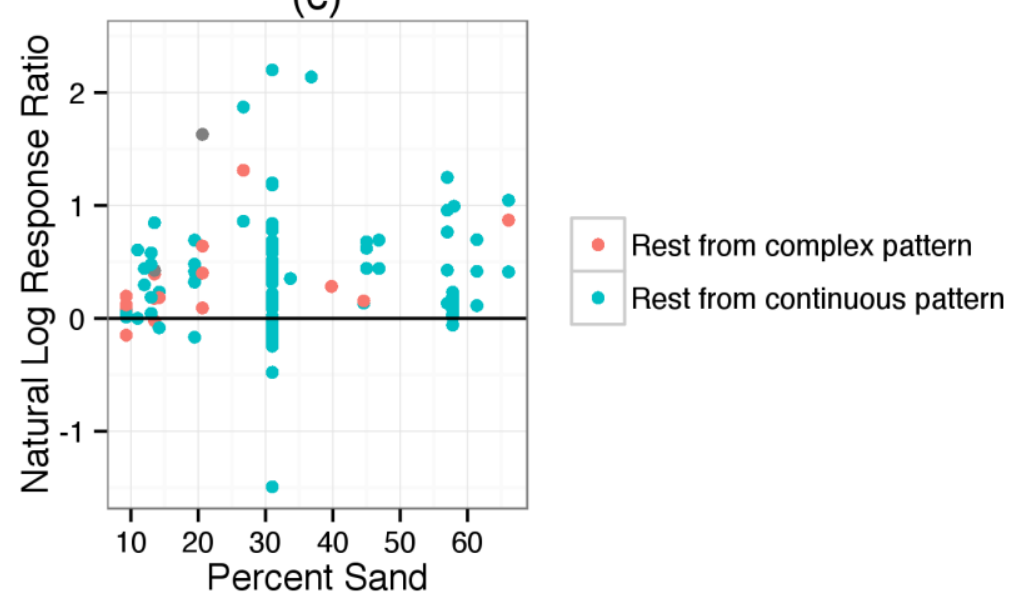

(b)

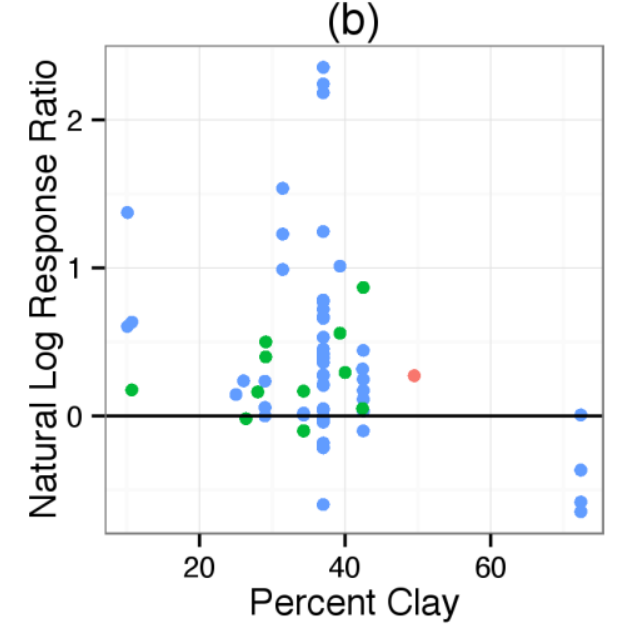

Agroforestry adoption

- Increased Complexity

Reduced Stocking Rate

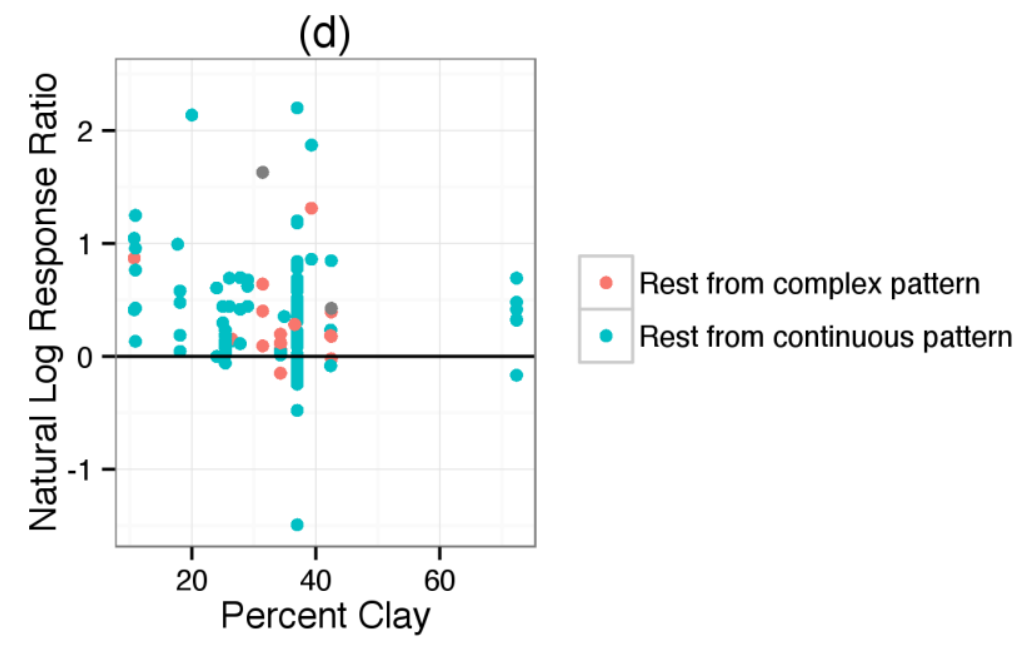




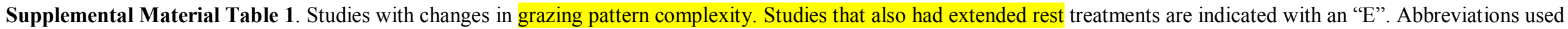

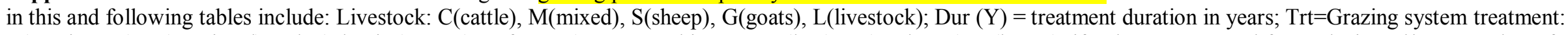

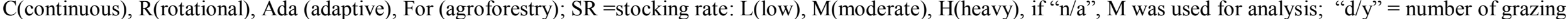

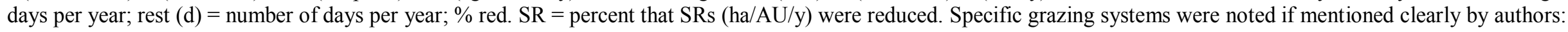

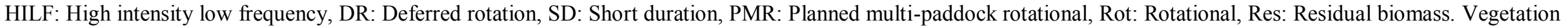
column highlights select features described by authors.

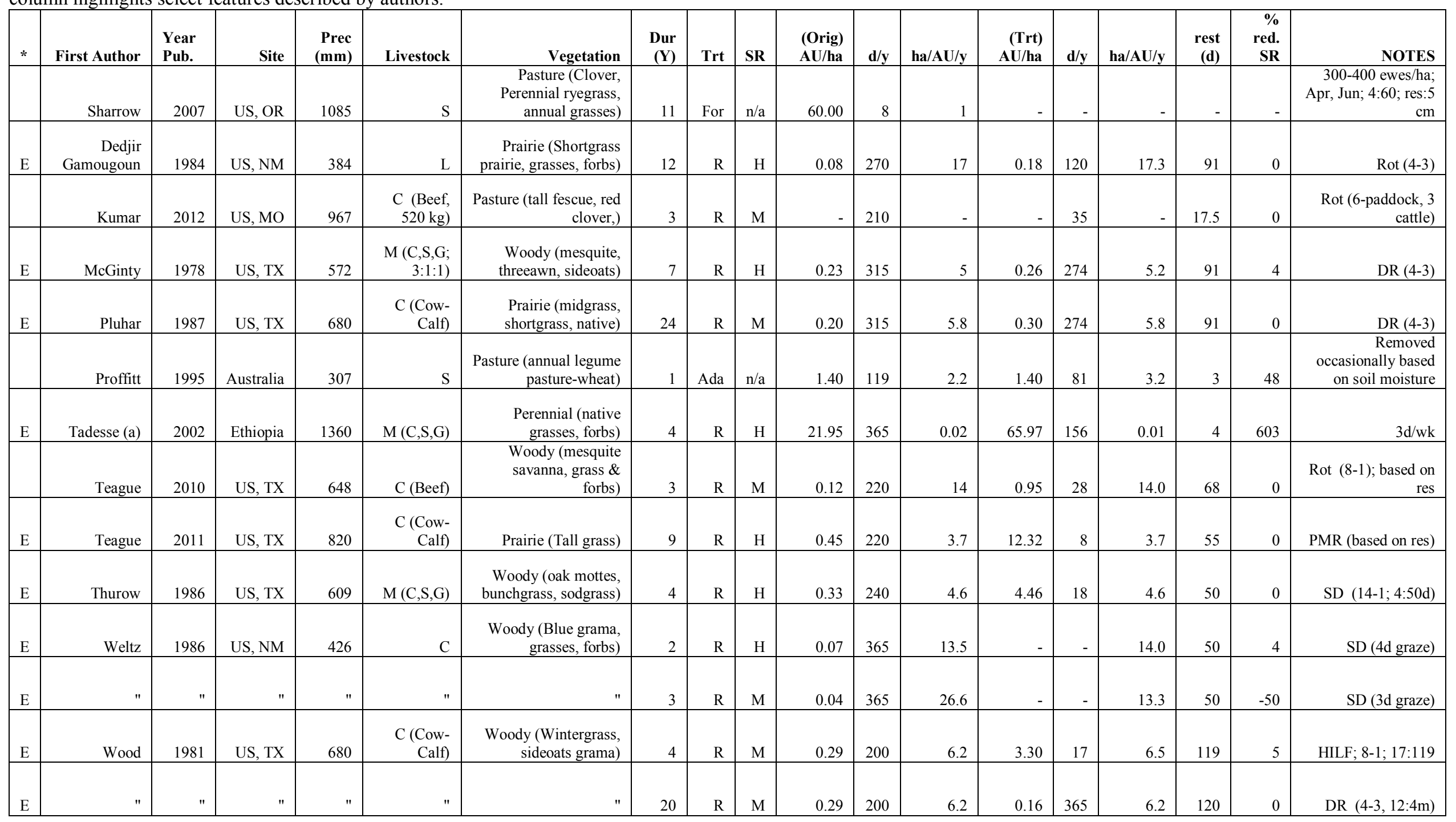




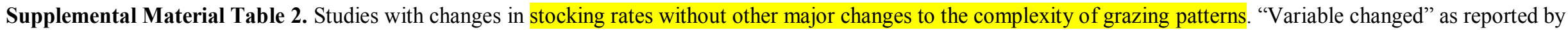

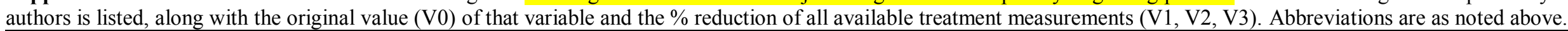

\begin{tabular}{|c|c|c|c|c|c|c|c|c|c|c|c|c|c|c|c|c|c|c|c|}
\hline & & & & & & & & & & & & & & & & $\%$ & reduction & & \\
\hline & First Author & Year & Site & $\begin{array}{l}\text { Prec } \\
(\mathbf{m m})\end{array}$ & Livestock & Vegetation & $\begin{array}{l}\text { Dur } \\
\text { (Y) }\end{array}$ & Sys & \begin{tabular}{|l|} 
SR \\
(Orig)
\end{tabular} & $\begin{array}{l}\text { SR } \\
\text { (Trt) }\end{array}$ & $\begin{array}{l}\text { (Orig) } \\
\text { AU/ha } \\
\end{array}$ & $\mathbf{d} / \mathbf{y}$ & $\mathbf{h a} / \mathrm{AU} / \mathbf{y}$ & $\begin{array}{l}\text { Variable } \\
\text { changed }\end{array}$ & Vo & V1 & V2 & V3 & NOTES \\
\hline $\mathrm{E}$ & Bari & 1993 & Pakistan & 625 & $\mathrm{~L}$ & $\begin{array}{l}\text { Grass (grasses, } \\
\text { forbes) }\end{array}$ & 2 & $\mathrm{C}$ & $\mathrm{H}$ & $\mathrm{M}, \mathrm{L}$ & - & - & - & $\begin{array}{l}\text { Res } \\
\text { phytomass } \\
(\mathrm{kg} / \mathrm{ha})\end{array}$ & 624 & 65 & 131 & - & \\
\hline & Chartier & 2011 & Argentina & 258 & $\mathrm{~S}$ & $\begin{array}{l}\text { Woody (Grass to } \\
\text { shrub steppe; } \\
\text { perennial grasses) }\end{array}$ & - & $\mathrm{C}$ & $\mathrm{H}$ & $\mathrm{M}, \mathrm{L}$ & 0.1 & 365 & 16.7 & Veg & $\begin{array}{c}\text { Grass } \\
\text { steppe }\end{array}$ & $\begin{array}{c}\text { Grass } \\
\text { steppe }\end{array}$ & $\begin{array}{l}\text { Shrub } \\
\text { steppe }\end{array}$ & - & $\begin{array}{l}0.3 \mathrm{~S} / \mathrm{ha} \\
\text { common }\end{array}$ \\
\hline $\mathrm{E}$ & $\begin{array}{l}\text { Dedjir } \\
\text { Gamougoun }\end{array}$ & 1984 & US, NM & 384 & $\mathrm{~L}$ & $\begin{array}{l}\text { Prairie (Shortgrass } \\
\text { prairie, grasses, } \\
\text { forbs) }\end{array}$ & 3 & $\mathrm{C}$ & $\mathrm{H}$ & $\mathrm{M}$ & - & - & 17.3 & ha/AU & 17 & 25 & - & - & $\begin{array}{l}\text { M SR = } \\
75 \% \mathrm{H} \\
\mathrm{SR}\end{array}$ \\
\hline $\mathrm{E}$ & du Toit & 2009 & S Africa & 366 & $\mathrm{~S}$ & $\begin{array}{l}\text { Woody (Common } \\
\text { shrubs, Karoo } \\
\text { bushes, grasses) }\end{array}$ & 2 & $\mathrm{C}$ & $\mathrm{H}$ & $\mathrm{M}, \mathrm{L}$ & 1.8 & 30 & 6.8 & $\mathrm{SSU} / \mathrm{ha}$ & 16 & 50 & 75 & - & \\
\hline E & Franzluebbers & 2011 & US, GA & 1250 & $\begin{array}{l}\mathrm{C} \text { (yearl. } \\
\text { steers) }\end{array}$ & $\begin{array}{l}\text { Pasture (bermuda } \\
\text { grass, tall fescue; } \\
\text { hayed } 1 / \text { mo to } 5 \mathrm{~cm}\end{array}$ & 12 & $\mathrm{C}$ & $\mathrm{H}$ & $\mathrm{L}$ & 4.1 & 270 & 0.3 & steer/ha & 9 & 33 & - & - & \\
\hline $\mathrm{E}$ & Mwendera & 1997 & Ethiopia & 1000 & $\begin{array}{l}\mathrm{C} \text { (cows, } \\
\text { oxen) }\end{array}$ & $\begin{array}{l}\text { Perennial (Native } \\
\text { grasses) }\end{array}$ & 1 & $\mathrm{C}$ & $\mathrm{V}$ & $\mathrm{L}, \mathrm{M}, \mathrm{H}$ & - & 365 & 0.8 & AUM/ha & 4 & 29 & 57 & 86 & \\
\hline E & Pluhar & 1987 & US, TX & 680 & $\begin{array}{l}\mathrm{C} \text { (Cow- } \\
\text { Calf) }\end{array}$ & $\begin{array}{l}\text { Prairie (midgrass, } \\
\text { shortgrass, native } \\
\text { range) }\end{array}$ & 1 & $\mathrm{R}$ & V & $\mathrm{H}$ & 12.5 & 8 & 3.6 & ha/cow/y & 13 & 66 & - & - & $\begin{array}{l}\text { both rot; } \\
\text { SR } \\
\text { constant }\end{array}$ \\
\hline $\mathrm{E}$ & Savodogo & 2007 & $\begin{array}{l}\text { Burkina } \\
\text { Faso }\end{array}$ & 841 & $\begin{array}{l}\text { M (C, S, } \\
\text { G, wild) }\end{array}$ & $\begin{array}{l}\text { Woody (savanna, } \\
\text { annual/perennial } \\
\text { grass) }\end{array}$ & 1 & $\mathrm{R}$ & V & $\mathrm{L}, \mathrm{M}, \mathrm{H}$ & 0.2 & 40 & 45.6 & $280 \mathrm{~kg} / \mathrm{d} / \mathrm{ha}$ & 8 & 25 & 50 & 75 & $\begin{array}{l}10 \mathrm{~d} \\
\mathrm{grz} / \mathrm{mo} ; 4 \\
\mathrm{mo}\end{array}$ \\
\hline $\mathrm{E}$ & Tadesse (a) & 2003 & Ethiopia & 1095 & $\mathrm{C}$ (cow) & $\begin{array}{l}\text { Perennial (Native } \\
\text { grasses, forbs) }\end{array}$ & 2 & $\mathrm{C}$ & $\mathrm{H}$ & M & - & 365 & 3.4 & AUM/ha & 4 & 57 & - & - & \\
\hline E & Taddese (b) & 2002 & Ethiopia & 1000 & $\begin{array}{l}\mathrm{C}(\mathrm{cow}, \\
\text { oxen) }\end{array}$ & $\begin{array}{l}\text { Perennial (Native } \\
\text { grasses) }\end{array}$ & 1 & $\mathrm{C}$ & V & $\mathrm{L}, \mathrm{M}, \mathrm{H}$ & - & 365 & 3.4 & AUM/ha & 4 & 29 & 57 & 86 & \\
\hline E & Teague & 2011 & US, TX & 820 & $\begin{array}{l}\text { C (Cow- } \\
\text { Calf) }\end{array}$ & $\begin{array}{l}\text { Prairie (Tall grass } \\
\text { prairie) }\end{array}$ & 9 & $\mathrm{C}$ & $\mathrm{H}$ & $\mathrm{L}$ & 0.4 & 220 & 3.7 & $\mathrm{AU} / 100 \mathrm{ha}$ & 27 & 48 & - & - & \\
\hline E & Thurow & 1986 & US, TX & 609 & $\begin{array}{l}\mathrm{M}(\mathrm{C}, \mathrm{G}, \\
\mathrm{S})\end{array}$ & $\begin{array}{l}\text { Woody (oak } \\
\text { mottes, bunchgrass, } \\
\text { sodgrass) }\end{array}$ & 6 & $\mathrm{C}$ & $\mathrm{H}$ & M & 0.3 & 240 & 4.6 & ha/AU/y & 5 & 43 & - & - & \\
\hline $\mathrm{E}$ & Warren (a) & 1986 & US, TX & 609 & $\mathrm{C}$ (heifers) & $\begin{array}{l}\text { Bare (herbicide + } \\
\text { drought ) }\end{array}$ & 1 & $\mathrm{R}$ & V & $\mathrm{M}, \mathrm{H}$ & 6.8 & 20 & 2.7 & ha/AU/y & 2.7 & 34 & 67 & - & $\begin{array}{l}\text { pre/post } \\
\& w e t / d r y\end{array}$ \\
\hline & Warren (b) & 1986 & US, TX & 609 & $\begin{array}{l}\mathrm{M}(\mathrm{C}, \mathrm{G}, \mathrm{S} \\
1.63: 1: 1)\end{array}$ & $\begin{array}{l}\text { Woody (Live oak, } \\
\text { grass, savanna) }\end{array}$ & 2 & $\mathrm{R}$ & $\mathrm{H}$ & $\mathrm{M}, \mathrm{L}$ & 2.9 & 26 & 4.8 & $\mathrm{ha} / \mathrm{AU}$ & 0.3 & 37 & 53 & - & $\begin{array}{l}\text { all rot; SR } \\
\text { const. }\end{array}$ \\
\hline $\mathrm{E}$ & Weltz & 1986 & US, NM & 426 & $\mathrm{C}$ & $\begin{array}{l}\text { Woody (Blue } \\
\text { grama, grasses, } \\
\text { forbs, etc.) }\end{array}$ & 18 & $\mathrm{C}$ & $\mathrm{H}$ & $\mathrm{M}$ & 0.1 & 365 & 13.5 & ha/AU & 14 & 25 & - & - & \\
\hline $\mathrm{E}$ & Wood & 1981 & US, TX & 680 & $\begin{array}{l}\text { C(Cow- } \\
\text { Calf) }\end{array}$ & $\begin{array}{l}\text { Woody (Winter } \\
\text { grass, sideoats } \\
\text { grama, mesquite) }\end{array}$ & 20 & C & $\mathrm{H}$ & M & 0.2 & 365 & 4.6 & ha/AU & 5 & 25 & - & & \\
\hline
\end{tabular}




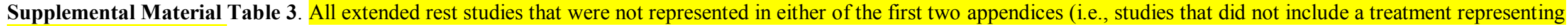
increased grazing pattern complexity or a reduction in stocking rates or pressure). Abbreviations are as noted above.

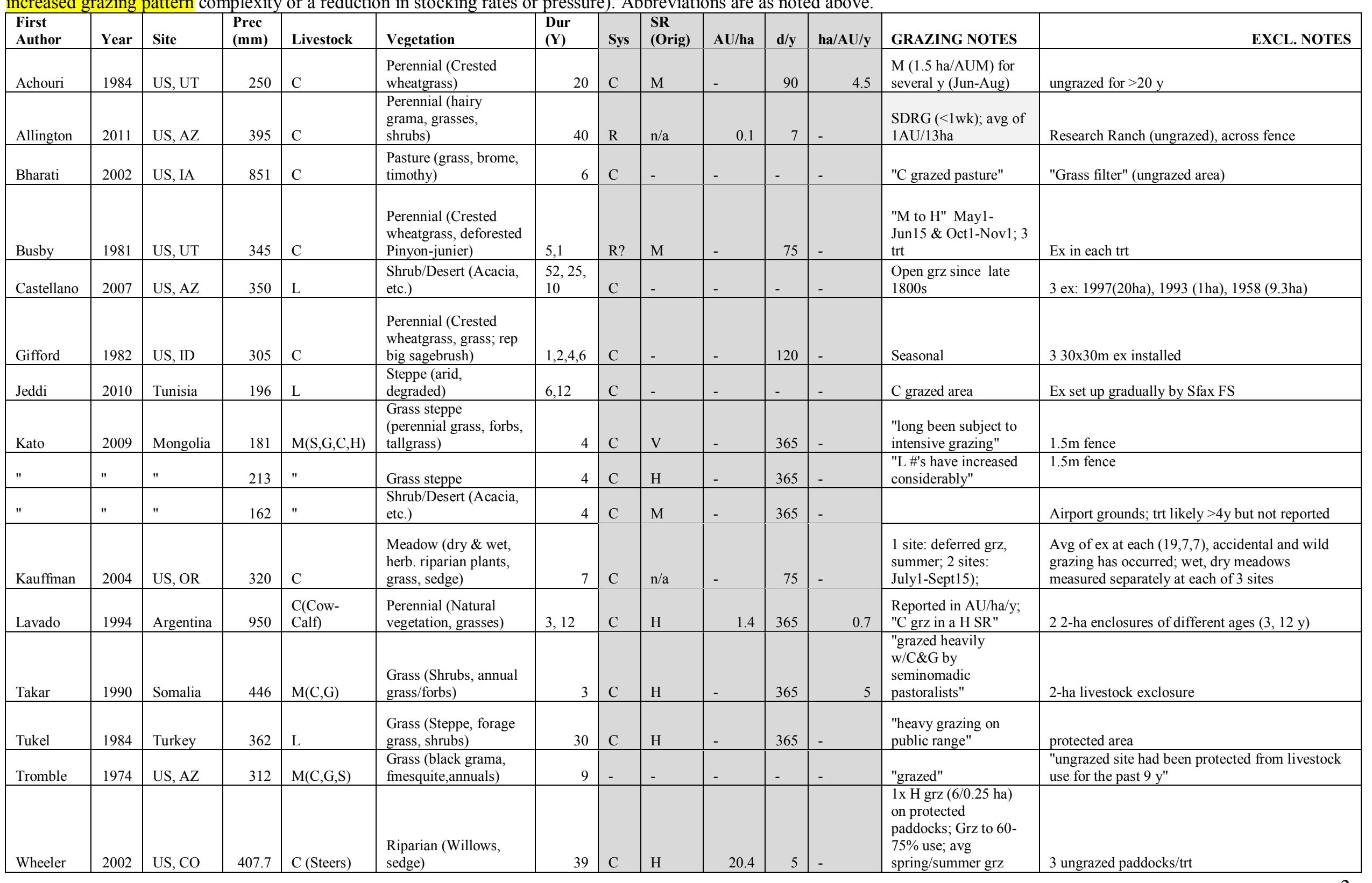


Supplemental Material Table 4. Animal unit equivalent values used for calculating stocking rates. In cases where a value was not provided in one of the papers from our database, commonly used values were assumed

(https://www.ag.ndsu.edu/archive/streeter/2006report/aums/Doing\%20the\%20Math.htm).

\begin{tabular}{|l|r|r|l|}
\hline Animal & kg & AUE & Reference \\
\hline Cow-calf & 450 & 1.0 & \\
\hline Bull & 630 & 1.4 & \\
\hline Steer & 383 & 0.9 & \\
\hline $\begin{array}{l}\text { Zebu } \\
\text { Cows/Oxen }\end{array}$ & 380 & 0.8 & \begin{tabular}{l} 
Mwendera \\
\hline Heifer
\end{tabular} \\
\hline Tropical LU & 250 & 0.8 & \\
\hline $\begin{array}{l}\text { Yearling } \\
\text { Angus Steer }\end{array}$ & 212 & 0.6 & Tadesse 2003 \\
\hline Sheep & 90 & 0.2 & 2011 \\
\hline $\begin{array}{l}\text { Small stock } \\
\text { unit }\end{array}$ & 50 & 0.1 & du Toit 2009 \\
\hline Sheep/Goats & 43 & 0.1 & Zhou 2012 \\
\hline
\end{tabular}

